\title{
Bağlam ve Süreç Temelli Yazma Becerisinin Gelişiminde Söylem Çözümleme Yönteminin Etkisi: Örnek Uygulama
}

\section{Dilek ÜNVEREN KAPANADZE*}

Öz: Söylem çözümleme yönteminin yazma becerileri üzerindeki etkisini incelemeye yönelik olarak yapılan, nicel ve nitel veri toplama araçlarının kullanıldığı bu karma desenli, ön test son test gruplu deneysel çalışmada öğrencilerin yazma uygulamaları çeşitli yollar ile değerlendirilmiş; 5 aşamalı yazma uygulamas1 ve 7 ölçütlü değerlendirme formu ile nicel veriler; görüşme formu ile de nitel verilerin toplanarak değerlendirilme yoluna gidilmiştir. Değerlendirme formundaki ölçütler göz önünde bulundurularak öğrenci yazıları belirlenen likert ölçeğine göre puanlanmıştır. 5 aşamalı yazma uygulamalarında, söylem çözümleme yöntemi ile işlenen metnin sonunda yapılan, öğrencilere verilen sorular dahilinde yapılandırdıkları yazma çalışmalarında öğrencilerin sorulara verdiği cevaplar, Uluslararası Öğrenci Değerlendirme Programında (PISA) olduğu şekilde değerlendirilmiştir. Katılımcılar 21 deney, 19 kontrol grubu olarak belirlenen 7. sınıf öğrencilerinden oluşmaktadır. Gruplar belirlenmeden önce ilgili sınıfların Türkçe öğretmenleri başta olmak üzere özellikle sosyal bilimler alanlarında derse giren öğretmenlerden öğrencilerin yazma becerilerinin düzeyi konusunda bilgi alınmıştır. Ayrıca gruplar oluşturulurken, öğrencilerin Türkçe dersi ve diğer derslerinin 6. sınıftaki ortalamaları ile 7. sınıf 1. dönem ortalamalarına da bakılarak, başarı düzeyleri birbirlerine yakın olan iki grup seçilmesine dikkat edilmiştir. Sonuç olarak öğrencilerin, metinlerini meydana getirirken söylem çözümlemenin imkânlarından yararlanarak düşüncelerin cümle ve paragraflarda nasıl yerleştirildiğini, sözcük ve cümle yapılarının anlama nasıl etki ettiğini, bu seçimlerin neden yapıldığını görebildikleri, yazma sürecinde de bu unsurları göz önünde bulundurarak metinleri yapılandırdıkları tespit edilmiştir. Ayrıca söylem çözümleme yönteminin Türkçe derslerinde kullanılması ve öğrencilerin anlama, yazma

*Dr. Öğretim Üyesi, Süleyman Demirel Üniversitesi, Eğitim Fakültesi, Email: dilekkapanadze@sdu.edu.tr, https://orcid.org/0000-0003-3415-9274.

$\begin{array}{lll}\text { Gönderim:27.08.2018 Kabul:09.12.2018 } & \text { Yayın:15.03.2019 }\end{array}$


gibi becerilerinin gelişimine katkıda bulunması hususunda da deney grubu öğrencileri görüş formlarında olumlu yönde görüş bildirmişlerdir.

Anahtar Sözcükler: Söylem çözümleme, yazma becerisi, anlama, bağlam, süreç temelli yazma

The Effect of Discourse Analysis Method on Developing Context and Process Based Writing

\section{Skills: A Sample Application}

Abstract: In this mixed methods research, experimental study with pre-test post-test group in which the quantitative and qualitative data collection tools were used to examine the effect of discourse analysis method on writing skills, the writing practices of the students were evaluated in various ways; quantitative data collected through 5-step writing practices and 7-criteria-evaluation form; and qualitative data collected and evaluated through interview forms. According to the criteria in the evaluation form, the student scores were marked based on a Likert scale. The answers structured by the students to the guiding questions in the 5-step writing practices which were conducted at the end of each process of analyzing texts through discourse analysis, were assessed as in the International Student Assessment Program (PISA): Full score (2), partial score (1) and zero score (0). Participants consisted of $7^{\text {th }}$ graders; 21 students in the treatment and 19 students in the control group. Before the groups were determined, information was obtained about the level of writing skills of the students, especially from the teachers of relevant classes, specifically from social studies and Turkish lessons. Additionally, while creating groups, it was also be ensured that two groups with similar achievement levels were selected by looking at the students' averages of Turkish lesson and the other courses of $6^{\text {th }}$ grade and 1 st semester of $7^{\text {th }}$ grade. As a result of the study, it has been found out that the students were able to recognize elements and process related to creating a text such as; how thoughts are placed in the sentences and paragraphs, how the words and sentences located in texts to affect understanding, why all these choices are made etc. by taking advantage of the opportunities of discourse analysis. In addition to these, they also expressed positive opinions on discourse analysis method to be used in Turkish lessons and that the method contributed to the development of skills such as comprehension and writing. 
KeyWords: Discourse analysis, writing skills, comprehension, context, process-based writing

\section{Giriş}

Yazma, duygu ve düşüncelerin sadece ifade edilmesi değil, aynı zamanda insanların bilgi ve tutarlı düşünce alışkanlığı kazanması ve zihinsel olarak olgunlaşması ile de sonuçlanabilecek bir süreçtir (Göğüş, 1978). Öyle ki yazma sürecinde kullanılan zihinsel işlemler, bir yandan zihin yapısını da düzenleme işlevine de sahip olması yönüyle, zihinsel gelişimde önemli bir noktada durmakta, hatta okumadan daha önemli olduğu bile vurgulanmaktadır (Güneş, 2013). Aktaş ve Gündüz (2003), yazmanın amacının, insanların gözlemlerinden, bilgi ve birikimlerinden yararlanma yoluyla edindiği duygu ve düşünceleri etkili ve doğru bir şekilde aktarmak olduğunu belirtirken; Göğüş (1978) ise; yazılı anlatımın genel amacının bireyin bir toplumsal kişilik kazanabilmek adına duygu ve düşünceleri karşı tarafa aktarma yeteneği kazanması olarak ifade eder.

Yazma eğitimiyle ilgili ilk çalışmalar okul öncesi döneme dayansa da, yazma becerisi, ilköğretim düzeyinde öncelikle kazanım aşamasıyla başlar (Akyol, 2009). İlkokul 2-3. sınıfta cümle; 45.sınıfta paragraf aşaması tamamlanmakta, dil gelişimi düzeyleri arttıkça, bireylerin cümleleri uzamakta, paragrafları da daha bütünlüklü, hedef odaklı ve bir düşünceyi geliştirme yönünde daha etkili olmaktadır (Acarlar ve Dönmez, 1992; Acarlar, Ege ve Turan, 2002; Ege, Acarlar ve Güleryüz, 1998)

Yazma çalışmaları, yazılı ifade ya da anlatım; cümle kurabilmeyi ve bunları belirli bir düşünceyi iletme amacı ile düzenlemeyi, cümleler arasında hem dil hem de düşünce açısından bağlantı kurmayı, cümleleri bir araya getirerek paragraflar gibi daha büyük anlamlı birimler oluşturmayı ve oluşturulan metin içindeki paragraflar arasında düşünceyi geliştirici bir yol izlemeyi gerektirir.

Yazılı anlatımda plan, düşüncelerin doğru ve etkili aktarımı için en önemli unsurlardan biridir. Gökşen (1980), yazının içeriğini oluşturacak düşüncelerin gelişigüzel yazılmayacağı, ilgi ve önem seviyelerine göre ayrılıp sıralanması gerektiğini belirtir. Anlatımın planı ya da anlatının kurgusu (Adalı, 2003) adı verilen bu süreç, neyin nerede yazılacă̆ı, neyden önce ya da sonra söylenmesi gerektiği ile ilgili bir durumdur. 
Öğrencinin yazma becerisi gelişim gösterdikçe, bilgiyi başka alanlara taşıma, düşünceleri düzenleme, gözden geçirme aşamasından sonra yeniden düzenleme daha etkili bir biçimde gerçekleştirilir, böylelikle daha ileri düzey yazıların ortaya çıkması sağlanmış olur (Akyol, 2006). Akıcı yazma olarak ifade edilen bu aşama öğrencinin artık anlam bütünlüğü oluşturan metinler meydana getirmesidir (Güneş, 2007). Bu, hem metin üretmenin belli bir süreci gerektirdiğini hem de ileri düzey düşünmeler gerçekleştikçe ileri düzey yazmaların da geliştiğini göstermektedir. Böylelikle, bu durum, üst düzey yazılı anlatım geliştikçe üst düzey düşünme becerilerinin de geliştiğine işaret etmesi açısından oldukça kıymetlidir.

Dil becerilerinin gelişim süreçleri birbirini destekler nitelikte ve bütünleyici bir şekilde ilerlemekte, dinleme ile başlayan süreç okuma ve yazma eğitiminin gerçekleşmesiyle tüm hayat sürecinde gelişim gösteren bir durum olarak karşımıza çıkmaktadır (Temizyürek ve Çevik, 2017). Ancak bilişsel düşünme süreçleri yeteri kadar gelişmediğinden yazma becerisi gelişimi diğer becerilere göre daha yavaş gerçekleşmektedir. Bu durum zihinsel gelişim ile dil becerilerinin gelişimi açısından önemli bir ilişskiyi ortaya koyarken (Karatay, 2011), yazma becerisinin gelişiminde zihinsel becerilerinin gelişiminin öncelenmesi, kimi zaman da eş zamanlı sürdürülmesini sağlayacak yöntemlere olan ihtiyacı göstermektedir.

\section{Söylem Çözümleme}

Söylem çözümleme kavramı, ilk kez dilbilimci Zellig Harris tarafından, bir metinde cümleleri birbirine bağlayan ilkenin ne olduğunu araştırırken kullanılmıştır. Harris, bir cümlenin neden diğerini takip ettiği yönündeki kurallar ararken söylem çözümleme için iki muhtemel yön tespit etmiştir (Ünveren, 2016). Bunlardan biri dil ve kültür bağlantısı, diğeri ise tek bir cümle sınırlarının ötesindeki sürekli betimleyici dilbilimdir (Harris, 1952). Söylem çözümleme daha sonra 1970’lerin sonunda araştırma alanlarının gündemine gelmiş, yöntemin yansımaları ilk olarak yorumbilim ile felsefi tartışmalar üzerinde ve dilin toplumsal gerçeklik üzerindeki yapıcı rolü üzerinde olmuştur (Fairclough, 1995; Gill, 1996; Potter ve Wetherell, 1987; Sinclair ve Coulthard, 1975; Titscher ve diğ., 2000; Van Dijk, 1985). 
Söylem çözümleme, sözlü ve yazılı metinler aracıllğıyla oluşan anlam çıktılarını ele alan geniş kapsamlı bir araştırma yöntemidir. Söylem çözümlemenin temel varsayımları arasında; dilin eylem ve işlev yönünde bir aracı olduğu, insanların dili niyetli bir şekilde, belli amaçlara yönelik olarak kullandıkları ve bu etkin kurgu sürecinin dilde çeşitlilik şeklinde yansıdığı vardır. Dil öğrenimi, bu anadil öğrenimi bile olsa, dilin dilbilgisi kurallarını bilmekten daha fazlasıdır, dili kullanım halinde ve söyleminde öğrenmeyi gerektirir. Dil, söylem içinde ifade edilir; söylem, bağlamda şekillenir ve bağlam da metin içinde oluşur. Yazılı söylemde yazınsal metinler, farklı söylemleri ve bağlamları farklı metin türlerinde sunarlar. Anadil veya ikinci dil öğretim sürecinin her seviyesinde metin kullanımı bulunmaktadır. Bu noktada önemli olan, metnin anlaşılmasıdır; bu da okuyucudan veya metinden kaynaklanan değişik şartlara bağlıdır. Bu bakımdan söylem çözümlemesi, metnin özüne ve derinliklerine inen karanlık sokaklarda yol gösterici niteliğinde belirir. Söylem çözümlemesi, dili cümle düzeyinden daha fazlası olarak kabul eder. Böylece yüzeyin altında yatan gizli öze ulaşmak, metinle okurun aynı dili konuşmasını sağlamak için cümle sınırlarının ötesine geçecek bir yöntem sunmuş olur.

İyi yazan öğrenciler, gerekli sözel beceriler ile düşünceleri düzenleme ve bir düzene göre yazma becerisine, uygun bilgi birikimine sahiptirler (Gersten ve Baker, 2001). Bununla birlikte, hem bilgi ve düşünceyi üretme hem de yazma sürecinde öğrencilere yol gösterecek; kendini izleme ile analiz edilen ve belli bir süzgeçten geçirilen düşüncelerin seçilip organize ederek okura sunulması yönünde rehberlik edecek strateji ve yöntemlere sahip olma ve bunları kullanabilme becerileri gerekmektedir. Sadece yazma sürecinde değil, yazıya başlamadan önce, bilgilerin ve verilenlerin analiz edilmesi, anlamlandırılması, en uygun ve etkili şekilde aktarılması adına ihtiyaç duyulan yöntem meselesinin ele alındığı bu çalışmada söylem çözümleme yönteminin, bahsi geçen gereklilikler, bilgi, birikim ve donanımları sağlama düzeyi açısından yazma becerisi üzerindeki etkisi ele alınacaktır. Bu bağlamda, söylem çözümleme yönteminin yazma becerisi üzerindeki etkisi nicel ve nitel veriler yoluyla tespit edilecektir.

\section{Söylem Çözümleme Yöntemi ile Yazma Eğitimi}


Yapılandırmacı yaklaşımda öğrenme; genel itibariyle yaşam boyu süren bir durumu ifade eder. $\mathrm{Bu}$ anlayışı benimseyenlere göre bilgi, yaşantılarını anlamlı kılmak isteyen birey tarafından yapılandırılmaktadır (Yurdakul, 2015). Bilgi, bu yaklaşımda edilgen bir şekilde alınmaz aksine birey tarafından etkin şekilde yapılandırılmakta hem bireysel hem de toplumsal olarak meydana getirilmektedir. Bununla beraber içeriğin organize edilmesi; öğrencilerin bilgiyi etkin bir biçimde yapılandırması; öğretmenin, öğrencilerin öğrenme çabalarına rehberlik etmesi; bilişsel fonksiyonların ve üst düzey düşünme becerilerinin etkin kılınması gibi özellikleri olan yapılandırmacı yaklaşım; bu hususiyetleriyle söylem çözümleme yönteminin beceri alanlarına olan katkısına kapı aralamaktadır.

Söylem çözümleme yönteminin genel referansları metni oluşturan kişinin yapılandırmasına dayanmaktadır. Metnin üretimine yönelik olarak kimin için üretildiği, bu konuda neden böyle bir metin yazılması gerektiği, aynı konunun farklı şekillerde yazılıp yazılamayacağı ve farklı yazma formlarıyla birleşip birleşmediği, metnin yazarı olarak kişinin konusuna karşı duruşu gibi üst düzey düşünmeler ve yapılar bağlamında yazma çalışması bu anlamda söylem çözümleme yöntemiyle yapılmaktadır. Bu yapılar haliyle yapılandırmacı yaklaşımın problem çözme, üretme, öğrenenin yaşantılarıyla ilgili öğrenme sorumluluğunu almasıyla da yakından ilgilidir.

Yazma çalışmalarında söylem çözümleme yöntemi uygulanırken öncelikle ön bilgiler dikkate alınır. Yeni bilgiler bu öğrenmeler üzerine inşa edilir. Öğrencinin katılımının istendiği bu yöntemde sınıf içi sosyal etkileşim adına ortam düzenlenir ve öğrenciler için sosyal bir öğrenme çevresi meydana getirilir. Süreçte otantik öğrenme ortamları yaratılarak söylem çözümlemenin toplum ve kültür bağlamında ne ifade ettiği üzerinden yaşama yakınlık ilgisi kurulur.

Öğrencilerin süreçte üst düzey düşünme becerilerini ortaya çıkaracak etkinlikler, yöntem ve teknikler işe koşularak bilgiyi yapılandırma sürecinin farkına varmaları sağlanır. Böylelikle öğrendiklerini yansıtacak yaşantılar düzenlenmiş olur. Öğrencilerin düşüncelerinin desteklendiği bu öğrenme ortamında, düşündüklerinin ve sözlü ve yazılı olarak ifade ettiklerinin değerli olduğu onlara sezdirilir. 
Söylem çözümleme bağlamında yazma çalışmasında metindeki dilin düşünsel anlama olan katkıs1, metni oluşturacak olan eylemler bütünü, koşullar, bağlam özelliği olarak kişiler arası anlam ilişkileri, dilin metinsel işlevi, dil bilgisi, eşdizimlilik başka bir deyişle sözcüklerin düzenli bir şekilde kullanılma biçimleri gibi yapılar bir arada düşünülür ve yazma çalışması yapılır. Bu yönleriyle söylem çözümleme, Türkçe derslerinden dört temel beceri alanında derslerde uygulanırsa, bu beceri alanlarına dair öğrencilerden beklediğimiz gelişimi görebilir, ürün olarak çıktılarını alabiliriz.

\section{Yöntem}

\section{Araştırma Modeli}

Nicel ve nitel veri toplama araçlarının kullanıldığ gruplu deneysel çalışmada öğrencilerin süreç temelli yazma uygulamaları çeşitli yollar ile değerlendirilmiştir. Bu araştırmadaki modelde ön testlerin bulunması, grupların deney öncesi benzerlik derecelerinin bilinmesine, son test sonuçlarının buna göre düzeltilmesine yardım eder (Balcı, 2011; Büyüköztürk, 2001; Hovardaoğlu, 2000; Karasar, 2013).

\section{Çalışma Grubu}

Söylem çözümleme yönteminin yazma becerileri üzerindeki etkisini incelemeye yönelik olarak yapılan bu deneysel çalışmada katılımcılar 21 deney, 19 kontrol grubu olarak belirlenen 7. sınıf öğrencilerinden oluşmaktadır. Çalışma grubu belirlenmeden önce okuldaki altı adet 7. sınıf şubesi hakkında, ilgili sınıfların Türkçe öğretmenleri başta olmak üzere özellikle sosyal bilimler alanlarında derse giren öğretmenlerden öğrencilerin yazma becerilerinin düzeyi konusunda bilgi alınmıştır. Ayrıca gruplar oluşturulurken, öğrencilerin Türkçe dersi ve diğer derslerin 6. sınıftaki ortalamaları ile 7. sınıf 1. dönem ortalamalarına da bakılarak, başarı düzeyleri birbirlerine yakın olan iki grup seçilmesine dikkat edilmiştir.

\section{Veri Toplama Araçları}


5 aşamalı yazma uygulaması ve 7 ölçütlü değerlendirme formu ile nicel veriler; doküman inceleme ve görüşme formu ile de nitel veriler toplanarak değerlendirilme yoluna gidilmiştir. Nitel araştırmalarda gözlem, görüşme gibi yöntemlerin yanında doküman tarama da kullanılan yöntemlerden biridir. Başta algılar olmak üzere olaylar doğal ortamı içerisinde gerçekçi ve bütünü yansıtacak şekilde ortaya konur (Yıldırım ve Şimşek, 2011). Öğrencilerin süreç içerisinde ortaya koydukları ürünler ve görüşleri bu doğrultuda analiz edilmiştir. Nitel veri araçlarından görüşme formu, araştırmacı, Türkçe öğretmenleri ve konunun diğer uzmanlarıyla birlikte hazırlanmıştır. Sürecin sonunda öğrencilerden 14 sorudan oluşan bu görüşme formunu cevaplamaları istenmiştir.

Nicel veri toplama araçlarından 7 ölçütlü değerlendirme formu araştırmacı tarafından oluşturulurken Türkçe Dersi Öğretim Programı 7. sınıf yazma kazanımları merkeze alınmıştır. İlgili programda belirtilen kazanımlara ulaştıracak yapılar içine söylem çözümleme yönteminin yazma becerilerine etki edecek unsurları tümlenmiştir. Form için önce 12 soru hazırlanmış, bu sorular program geliştirme uzmanı, Türkçe öğretmenleri ve söylem çözümleme alanında çalışmış kişilere ulaştırılarak görüşleri alınmıştır. Sorularla ilgili olarak alınan görüşler görüş birliği/görüş ayrıllı̆g 1 şeklinde tasnif edilmiş ve görüş birliğinin yüksek olduğu 7 soru bu forma alınarak öğrencilere uygulanmıştır. Formun geçerliliği için yüzey geçerliliği (mantıksal geçerlilik) araştırması yapılmıştır. Bu bağlamda; alan uzmanlarından görüşler alınmış; asıl çalışma grubunun dışında oluşturulmuş olan cevaplayıcıların da kanaatlerine başvurulmuştur. Bunun yapılmasının nedeni; yazma çalışması için araştırılan yapı ile olgular arasında anlamlı bir ilişkinin olup olmadığı ile yazma için belirlenen ifadelerin hedef kitleye uygun olup olmadığının anlaşılmak istenmesidir. Böylelikle formun güvenirlik ve geçerlik çalışmaları tamamlanarak uygulamaya konmuştur.

\section{Verilerin Analizi}




\section{Nicel Veri Analizi}

Nicel araştırmaların doğası gereği en temel özelliği elde edilen bulguların sayısal veriler şeklinde ölçülüp ifade edilmesi ve dayanılan söz konusu hipotezlerin test edilebilir olması ilkesi bu çalışmalarda öne çıkmaktadır. Araştırmanın nicel bölümünde bu ilkeye dayanarak çalışmaya konu olan değişkenlerin yazma becerileri üzerindeki etkileri araştırılmıştır.

Yazma çalışması sürecinde, dört farklı metin işlenmek kaydıyla yazma çalışması yapılarak, yazma becerisine yönelik gözlemlenmek istenen durumlar bağlamında geliştirilen 7 ölçütlü değerlendirme formu, sürecin başından sonuna değin her bir çalışma için kullanılmıştır. Sonuçlar grafikler halinde sunulmuştur. Bu alanlar şu şekilde belirlenmiştir:

1. Yazma için amaç belirlemiştir.

2. Konuya uygun giriş yapmıştır.

3. Planlı yazma kurallarına uymuştur.

4. Söylem çözümleme yöntemiyle yazma amacina uygun seçimler yapabilmiştir.

5. Cümlede dil bilgisi kurallarının ve kullanılma şekillerinin anlama katkı yaptığı bilinciyle yazılarını oluşturmuştur.

6. Yazma amacına uygun şekilde metni oluşturmuştur.

7. Metni çözümledikten sonra yazdığı yazılarda etkili organizasyon, analiz, sentez becerilerini kullanma konusunda başarılı olmuştur.

Değerlendirme yapılırken öğrenci yazıları belirlenen likert ölçeğine göre derecelendirilerek puanlanmıştır. Ayrıca değerlendirme formlarında, öğretmen gözlem alanı adında bir bölüm açılarak, değerlendirme formu ölçütlerinde yer almayan ama öğretmen tarafindan gözlemlenen durumların da destekleyici veri olarak kullanılmasına olanak sağlanmıştır. Bu değerlendirme formundaki veriler sayısal olarak ifade edilirken süreksiz verileri göstermek için daire grafikten yararlanılmıştır. Grafik, frekans ve yüzdelik olarak ifade edilmiş, böylece öğrencilerin süreç içerisindeki gelişimleri ortaya konulmak istenmiştir. Grafikler yukarıda ifade edilen her metin işleme süreci için oluşturulmuştur. En sonda öğrencilerin söylem çözümleme yöntemiyle yazma becerilerindeki gelişim seyrini göstermek adına bütün grafiklerin ortalamaları da çizgi grafikle ifade edilmiştir.

Bununla birlikte; bu çalışmada gerçekleştirilen 5 aşamalı yazma uygulaması gereği, söylem çözümleme yöntemi ile işlenen metnin sonunda yapılan, öğrencilere verilen sorular dahilinde 
yapılandırdıkları yazma çalışmalarında öğrencilerin sorulara verdiği cevaplar, PISA’da (International Student Assessment Program- Uluslararası Öğrenci Değerlendirme Programı) olduğu gibi değerlendirilmiştir: Tam puan (2), Kısmi puan (1), Sıfır puan (0). Değerlendirme sürecinde her aşamada her metnin ön test uygulamasıyla arasındaki farkına bakılmıştır. Bu fark analizi için parametrik analiz teknikleri işe koşulmuştur. Yazma ürünlerinin değerlendirilmesi çalışması üç farklı değerlendirme yapan kişi tarafından yapılan değerlendirmeler belirlenen Likert ölçeğine göre puanlanmıştır. Daha sonra aynı gruba ait iki ortalamanın arasında anlamlı bir farkın olup olmadığının bilinmesi için bağımlı çalışma grubu için t-test kullanılarak ölçüm yapılmıştır. Yapılan analizler sonucunda puanlar arasında anlamlı bir fark olup olmadığı tespit edilmiştir. Elde edilen istatistiklere de tablolar halinde bulgular bölümünde yer verilmiştir.

\section{Nitel Veri Analizi}

Araştırmanın nitel deseninde ise, nitel araştırma yaklaşımı ve bileşenleri bağlamında araştırmaya konu olan olguların görüşme ve doküman inceleme yoluyla ortaya çıkarılması, anlamlandırılması yoluna gidilmiştir. Bu anlamda çoklu veri toplama araçları kullanılmış, elde edilen veriler derinlemesine bir şekilde analiz edilmiştir.

Görüşme formu verileri için, metin incelemelerinde kullanılan içerik analizi yöntemiyle elde edilen olguların belli başlıklar şeklinde tasnif edilmesi (Yıldırım ve Şimşek, 2011); anlamına gelen kategorisel analiz tekniği kullanılarak bulgular değerlendirilmiş, kod, kategori ve temalar oluşturulmak kaydıyla bir bütünlük oluşturulması yoluna gidilmiştir. Nitel verilerin güvenirliği ve geçerliği adına öğrencilerin formdaki sorulara verdiği cevaplar konunun uzmanı başka kişiler tarafından da kodlanmış, birbirleriyle karşılaştırılmış ve görüş birliği ve ayrılığı şeklinde yeniden tasnif edilmiştir. Görüş birliği/ (Görüş birliği+ Görüş ayrıllı̆ı x 100 formülü (Miles ve Huberman, 1994) kullanılarak kodlayıcılar arasındaki güvenirliğe bakılmış, bu bağlamda araştırmanın güvenirliliği \%84 olarak hesaplanmıştır. Ayrıca öğrencilerin formlara verdikleri cevaplar betimsel olarak da bu analize aktarılmıştır.

\section{Bulgular}




\section{Nicel Verilerin Analizi}

\section{Beş Aşamalı Yazma Uygulaması Değerlendirmeleri}

Ön uygulama çalışması ile başlayıp son uygulama çalışması ile sona eren çalışmanın bu bölümünde, bu süreçler sonucu elde edilen istatistiki veriler tablolar halinde verilerek bunların karşılaştırılması yoluna gidilmiştir.

\section{Tablo 1}

Deney ve Kontrol Grupları Ön ve Son Test t-test Sonuçları

\begin{tabular}{lccccc}
\hline & $\mathrm{N}$ & $\overline{\mathrm{x}}$ & $\mathrm{S} / \sigma$ & $\mathrm{t}$ & $\mathrm{p}$ \\
\hline Ön Test Kontrol Grubu & 19 & 1.2105 & .71328 & -.900 & .380 \\
\cline { 1 - 4 } Son Test Kontrol Grubu & 19 & 1.3684 & .49559 & & \\
\hline Ön Test Deney Grubu & 21 & 1.0000 & .63246 & -10.683 & .000 \\
\hline Son Test Deney Grubu & 21 & 6.579 & 2.0976 & &
\end{tabular}

Deney ve kontrol gruplarının öntest yazma uygulamalarının sonuçları karşılaştırılmış, ortalamaları ve standart sapmaları verilmek kaydıyla aralarında fark olup olmadığı görülmek istenmiştir. $\mathrm{P}=.331$ olarak bulunmuştur. Bulunan bu değerin $\mathrm{P}>0.05$ 'ten büyük olması sürecin hemen başında deney ve kontrol grupları arasında büyük ve anlamlı bir farkın olmadığını göstermektedir.

Kontrol grubunun ön ve son yazma uygulama puanları arasında istenen yönde ve düzeyde anlamlı bir fark bulunamamıştır. Yapılan t-test sonrasında deney grubunun ön test ve son test puanları sonucu $\mathrm{P}=.000$ olarak bulunmuştur. Bulunan bu değerin $\mathrm{P}<0.05$ 'ten küçük olması, ön test ve son test puanları arasında, başka bir deyişle, iki ölçüm arasında anlamlı bir farkın olduğunu göstermektedir.

Deney ve kontrol gruplarının süreç sonundaki yazma uygulamalarının karşılaştırılması için yapılan t-test sonrasında deney grubu için t-test sonucu $\mathrm{P}=.000$ olarak bulunmuştur. $\mathrm{Bu}$ da deney grubunun başarısının arttığını ve deney grubu ile kontrol grubu arasında anlamlı bir fark olduğunu göstermektedir. Aşağıdaki Tablo 2'de ise deney grubunun öntest ve Türküler Dolusu metnine dair elde edilen sonuçlar karşılaştırılmıştır:

\section{Tablo 2}

Deney Grubu Ön test (Ben Bir Küçük Kilimim) ve Türküler Dolusu Metni t-test Sonuçları. 


\begin{tabular}{lccccc}
\hline & $\mathrm{N}$ & $\overline{\mathrm{x}}$ & $\mathrm{S} / \sigma$ & $\mathrm{t}$ & $\mathrm{p}$ \\
\hline Ben Bir Küçük Kilimim & 21 & 1.0000 & .63246 & -12.823 & .000 \\
\hline Türküler Dolusu & 21 & 8.2381 & 2.42703 & & \\
& & & & &
\end{tabular}

Deney grubu öğrencilerine süreç başında yapılan ön test (Ben Bir Küçük Kilimim) ile sürecin ikinci haftasında, söylem çözümleme yöntemi ile işlenen Türküler Dolusu adlı metnin işlenmesi sonrasında yapılan yazma uygulaması karşılaştırılmıştır. Ön test sonuçları ve Türküler Dolusu metnine dair sorulan soruların sonuçları arasında fark olup olmadığı belirlenmeye çalışılmıştır. Yapılan t-test sonucu $\mathrm{P}=.000$ ve $\mathrm{P}<0.05$ 'ten küçük olarak bulunmuş; ön testte 1.000 olan öğrencilerin yazma uygulaması ortalamasının da Türküler Dolusu adlı metne dair yapılan uygulamada 8.2381'e yükseldiği tespit edilmiştir. Süreç başında yapılan ön test ile Türküler Dolusu metninin sonunda yapılan yazma uygulamalarının karşılaştırılması sonucunda, Türküler Dolusu metni ve yazma uygulaması değerlendirme sonuçları lehine anlamlı bir fark olduğu görülmüştür.

Bu aşama yapılandırılırken Türküler Dolusu adlı metin işlenmiş ve metne dair sorulan sorular yoluyla öğrencilerden, Türkçede zaman, görünüş ve kiplik temelinde değişik işlevleri olan bitimli biçimlerin yani geleneksel dilbilgisindeki ifadesiyle zaman ekleri ve şekillerin, şiir metinlerinde birer söylem tipi olarak üstlendikleri işlevleri irdelemek ve bu söylem tiplerinin söylem çözümleme ile bir betimlemesinin yapılarak yazılacak metne yansıtılması istenmiştir.

Ayrıca herhangi bir yazının metin olmasında ve metne anlam katma konusunda bağdaşıklık ilkelerinin, söylemin biçimini ve içeriğin nasıl düzenlendiğini ortaya koyan bir bağlam özelliği olduğu üzerinde durularak yine söylemin üretildiği bağlamın da yazarın bir görüşü benimsediğini ortaya koyan en önemli etmenlerden biri olduğu ifade edilmiş̧tir. Söylem sırasında yani metin oluşturulurken ve metinde kullanılan olgular, kelime seçimleri, inanışlar $v b$. diğer özelliklerin haliyle yazarı belli bir görüşün temsilcisi durumuna getirdiği de hatırlatılarak Türküler Dolusu adlı metin işlenmiş ve yazma çalışması için 4 yönlendirici soruyla metinler oluşturmaları istenmiştir. 
Aşağıdaki Tablo 3'te ise deney grubunun öntest ve Mutluluk Nedir metnine dair elde edilen sonuçlar karşılaştırılmıştır:

\section{Tablo 3}

Deney Grubu Ön test (Ben Bir Küçük Kilimim) ve Mutluluk Nedir Metni t-test Sonuçları.

\begin{tabular}{lccccc}
\hline & $\mathrm{N}$ & $\overline{\mathrm{x}}$ & $\mathrm{S} / \sigma$ & $\mathrm{t}$ & $\mathrm{p}$ \\
\hline Ben Bir Küçük Kilimim & 21 & 1.0000 & .63246 & -18.641 & 0.14 \\
\hline Mutluluk Nedir? & 21 & 7.6190 & 1.20317 & & \\
\hline
\end{tabular}

Deney grubu öğrencilerine süreç başında yapılan ön test (Ben Bir Küçük Kilimim) ile söylem çözümleme yöntemi ile işlenen Mutluluk Nedir? adlı metnin işlenmesi sonrasında 2 yönlendirici sorudan oluşan yazma uygulamaları sonuçları arasında fark olup olmadığı belirlenmeye çalışılmıştır. Yapılan ttest sonucu $\mathrm{P}=0.14$ ve $\mathrm{P}<0.05$ 'ten küçük olarak bulunmuş, böylelikle de ön testte 1.000 olan öğrencilerin yazma uygulaması ortalamasının Mutluluk Nedir? adlı metne dair yapılan uygulamada 7.6190'a yükseldiği tespit edilmiştir. Başka bir deyişle, süreç başında yapılan ön test ile Mutluluk Nedir? metnine dair yapılan yazma uygulamalarının karşılaştırılması sonucunda, Mutluluk Nedir? metni lehine anlamlı bir fark olduğu görülmüştür

Çalışmanın bu aşamasında Mutluluk Nedir? adlı metnin işlenmesi sürecinde, metnin oluşturulması sürecini anlamak adına yazarın bakış açısının bilinmesi, okura sunulan bilgilerin bir kısmının ortaya çıkarılmasında ve metnin söylem değerinin çözümlenmesinde önemli argümanlardan biri olduğunun fark edilip edilmediği hususunun anlaşılması istenmiştir.

Yine metnin türünü de belirlemeye yönelik olarak yazarın niyetini ve okuru çekmek istediği amaca yönelik dilsel tercihleri belirlemenin okuyucunun türün genel mantıksal yapısını ortaya çıkarmasına yarayacağı ifade edilmiştir. Bu zihinsel yapının aynı zamanda söylemin bir bütün olduğunu ortaya koyacağı, söylemin içerik ve şekliyle ilgili dilsel seçimlerin nasıl oluştuğunu da göstereceği üzerinde durulmuştur. Bu anlamda metinle ilgili olarak iki yönlendirici soru bağlamında bu unsurları ortaya koyabilecekleri yazma çalışmaları uygulanmıştır. 
Aşağıdaki Tablo 4’te deney grubunun öntest ve Klz Kalesi metnine dair elde sonuçlar karşılaştırılmıştır:

\section{Tablo 4}

Deney Grubu Ön test (Ben Bir Küçük Kilimim) ve Klz Kalesi Metni t-test Sonuçları.

\begin{tabular}{lccccc}
\hline & $\mathrm{N}$ & $\overline{\mathrm{x}}$ & $\mathrm{S} / \sigma$ & $\mathrm{t}$ & $\mathrm{p}$ \\
\hline Ben Bir Küçük Kilimim & 21 & 1.0000 & .63246 & -19.030 & .000 \\
\hline Kız Kalesi & 21 & 5.4762 & .74960 & & \\
\hline
\end{tabular}

Deney grubu öğrencilerine süreç başında yapılan ön test (Ben Bir Küçük Kilimim) ile sürecin dördüncü aşamasında Klz Kalesi adlı metnin söylem çözümleme yöntemiyle işlenmesinin ardından 3 yönlendirici soru ile yazma uygulamaları yapılmıştır. Ön test sonuçları ve Kız Kalesi metninin sonuçları arasında fark olup olmadığı belirlenmeye çalışılmıştır. Yapılan t-test sonucu $\mathrm{P}=.000$ olarak ve $\mathrm{P}<0.05$ 'ten küçük olarak bulunmuştur. Böylelikle de süreç başında yapılan ön test ile Klz Kalesi metninin karşılaştırılması sonucunda, öğrencilerin yazma uygulamalarının sonuçlarının öntest ortalaması olan 1.000 'dan 5.4762 'e yükseldiği; başka bir deyişle, Klz Kalesi metni lehine anlamlı bir fark olduğu tespit edilmiştir.

Çalışmanın bu aşamasında Klz Kalesi adlı metin, yazma çalışması süreci içinde işlenirken söylem çözümlemede, metinde ifade edilen ya da edilmeyen olgu, durum vb. diğer ögelerin çözümlenmesi için metnin sosyo-kültürel arka planının hem bilinmesi hem de çözümlenmesi gerekebileceği, bu durum her ne kadar metin ile toplum arasındaki ilişkiyi anlamlandırmak adına ortaya konsa bile aynı zamanda derin yapıların, söylenmemiş olanların, metnin kültürel bilinçaltının anlaşılabilmesi adına da kayda değer bir önerme olduğu öğrencilere sezdirilmiştir.

\section{7 Ölçütlü Değerlendirme Formu Sonuçları}


Ön test metnine dair yazma uygulaması ile söylem çözümleme yöntemi ile işlenen her bir metnin yazma uygulaması 7 ölçütlü değerlendirme formuna göre de değerlendirilmiş, yöntem bölümünde açıklandığı üzere likert belirlenerek sonuçlar tespit edilmiştir. Her öğrencinin ve bütün sınıfın puanları ve ortalamaları hesaplanarak aşağıdaki grafiklere yansıtılmıştır. Grafiklerdeki ortalama ve toplam puanlar süreçte öğrencilerin aşama kaydedip etmediklerini göstermesi açısından önemlidir. Her uygulama sonunda puanların ve ortalamaların arttı̆ğ görülmüştür. Bu bölümün en sonunda da öğrencilerin her bir metne dair kaydettikleri ilerleme tek bir çizgi grafik üzerinde gösterilmiştir. Grafiklerin yanında belirtilen sayılar soruların numaralarını ifade etmektedir.

Grafik 1: Deney Grubu Ön test (Ben Bir Küçük Kilimim) Değerlendirme Formu Soru Yüzdeleri

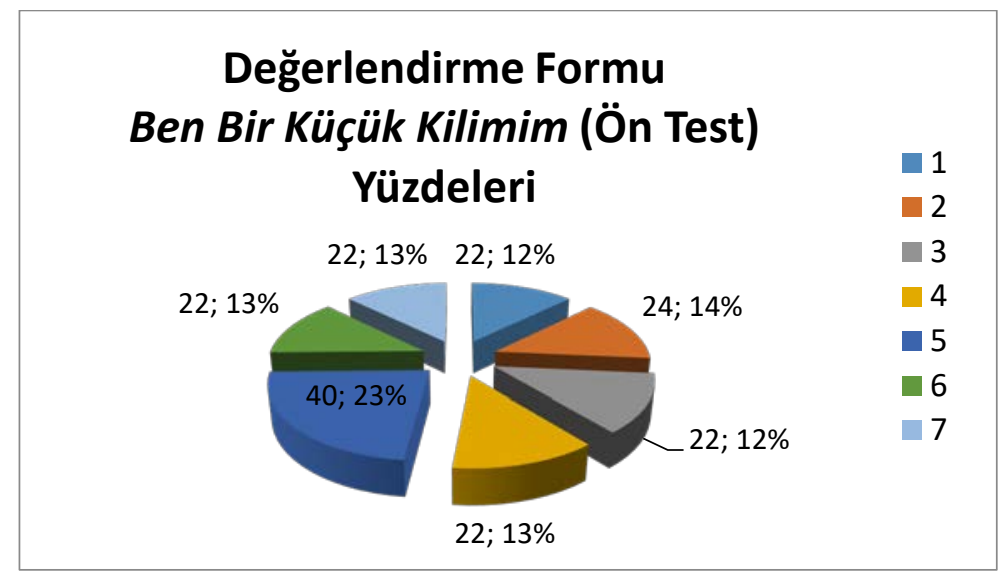

Ön test uygulaması şeklinde verilen yazma çalışmasında, öğrencilerin, Ben Bir Küçük Kilimim metnine verdikleri cevaplar, değerlendirme formundaki ölçütler doğrultusunda değerlendirilerek, her bir ölçüte göre aldıkları puanlar ve her ölçütün, değerlendirme formundaki 7 ölçütün tamamına oranı yüzdelik olarak Grafik 1'de gösterilmiştir. Böylelikle, deney grubunun yazma becerisine dair belirlenen ölçütler içerisinde sergiledikleri başarı ortaya konmuştur. Örneğin, 1. yazma becerisi ölçüt alanında, belirlenen likert hesabına göre öğrencilerin toplam puanı 22 olarak bulunmuştur. Öğrencilerin, diğer ölçüt alanlarına göre de puanları toplanmış, buna göre öğrencilerin 1. ölçüte göre başarıları \%12 olarak tespit edilmiştir.

Grafik 2: Deney Grubu Türküler Dolusu Metni Gözlem Formu Soru Yüzdeleri 


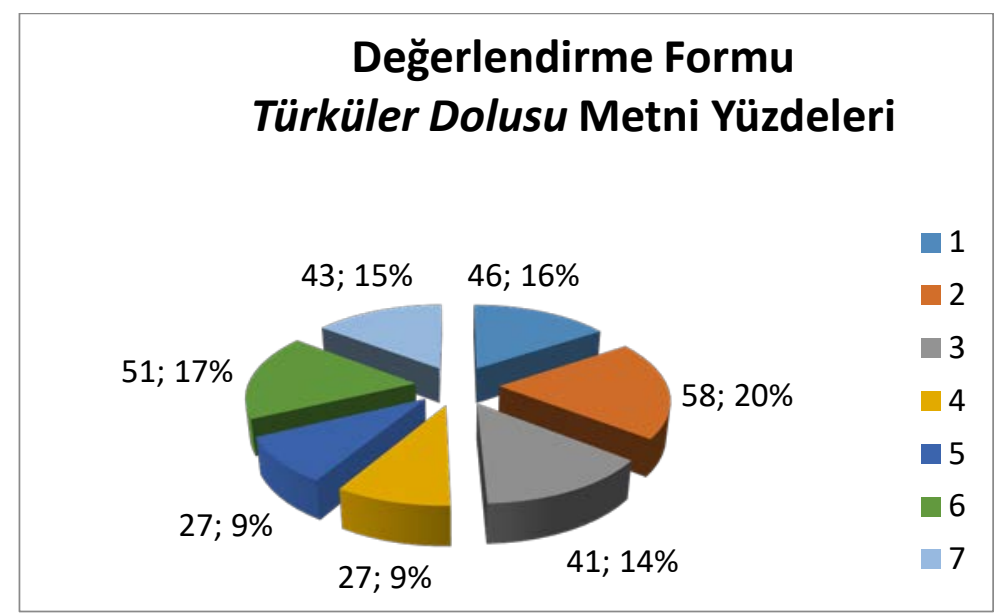

2. aşamada Türküler Dolusu yazma uygulamalarının değerlendirme formuna göre sonuçları çıkarılmıştır. Bu durumda, öğrencilerin ön test uygulamasındaki grafiğe göre Türküler Dolusu adlı metne dair yazma çalışmasında kaydettikleri aşama Grafik 2'de gösterilmiştir. Bu metne dair yazma süreci içerisinde değerlendirme formunda yer alan bazı ölçütler öncelendiğinden, diğer ölçütlerde daralma gözlemlenebilse de genel itibariyle bir ilerleme tespit edilmiştir.

Grafik 3: Deney Grubu Mutluluk Nedir? Metni Değerlendirme Formu Soru Yüzdeleri

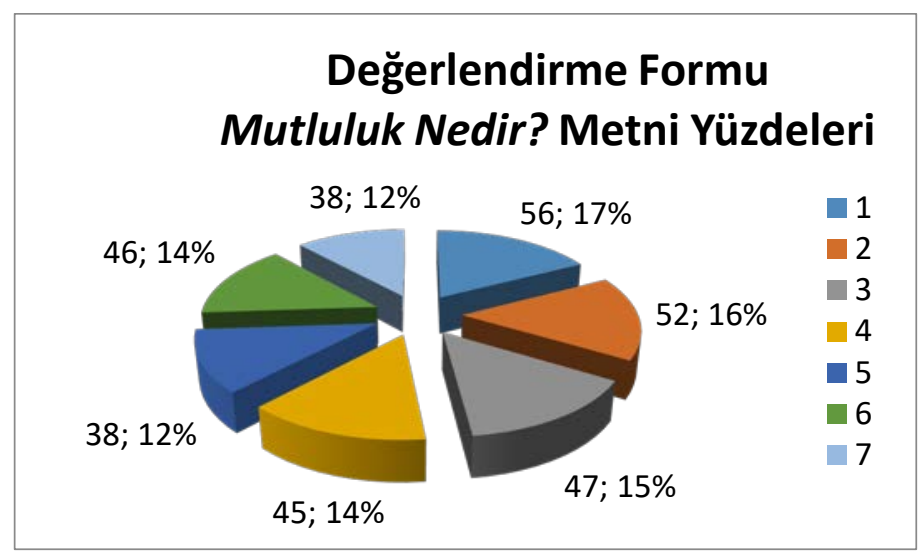

Mutluluk Nedir? metninin değerlendirme formunda yer alan öğrenci puanlarının toplamı ve ortalamaları alınarak grafik oluşturulmuş; ön test ve Türküler Dolusu uygulaması için belirtilen grafiklere göre, öğrencilerin kaydettikleri aşama sergilenmiştir. Bu yazma çalışmasında metindeki söylemin biçimi göz önünde bulundurularak 1, 3, 4 ve 7. kriterler ön plana alınmış, bu anlamda gözlemlenen ilerleme Grafik 3’te gösterilmiştir. 
Grafik 4: Deney Grubu Kız Kalesi Metni Değerlendirme Formu Soru Yüzdeleri

\section{Değerlendirme Formu Kız Kalesi Metni Yüzdeleri}

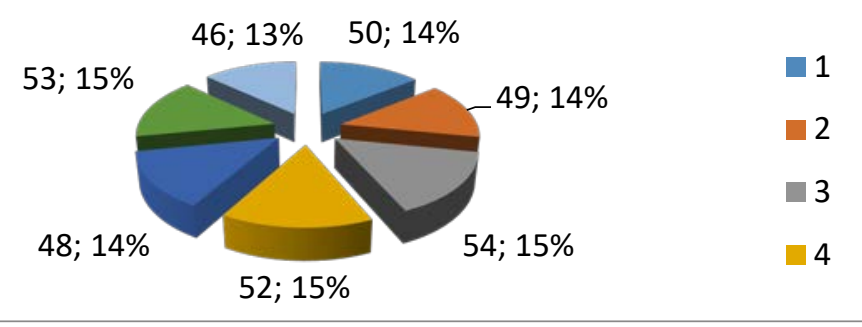

Klz Kalesi metninin 7 ölçütlü değerlendirme formunda yer alan öğrenci puanlarının toplamı ve ortalamaları alınarak grafik oluşturulmuştur. Ön test, Türküler Dolusu ve Mutluluk Nedir? uygulamaları için belirtilen grafiklere göre öğrencilerin kaydettikleri aşama Grafik 4'te gözlemlenmektedir. Kız Kalesi metni yazma çalışmasında bağlama katılan unsurlar, başka bir deyişle, dilin kişiler arası işlevi göz önünde bulundurulmuş; bu noktada öncelenen 3, 4, 5, 6 ve 7. ölçütlerde bir ilerleme kaydedildiği gözlemlenmiştir.

Grafik 5: Deney Grubu Son Test (Ben Bir Küçük Kilimim) Metni Değerlendirme Formu Soru Yüzdeleri

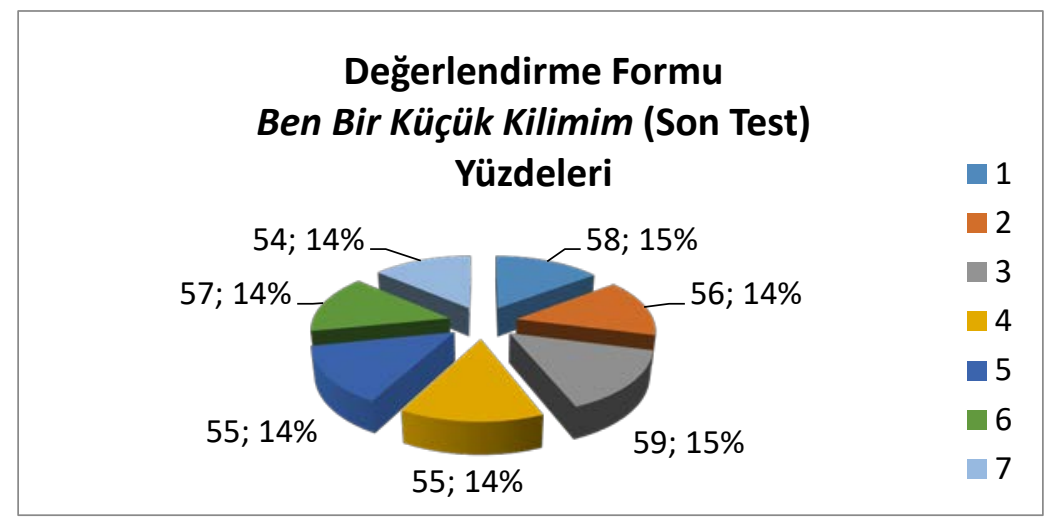

Aynı zamanda ön test olarak da uygulanmış olan Ben Bir Küçük Kilimim metninin son test olarak yapılan yazma uygulaması için değerlendirme sonuçları çıkarılmıştır. Ön test ve Türküler Dolusu, Mutluluk Nedir, Klz Kalesi uygulamaları için belirtilen grafiklere göre öğrencilerin kaydettikleri aşama ve ilerleme Grafik 5’te gösterilmiştir. 7 haftalık bir yazma sürecinin sonunda tekrar uygulanan bu yazma çalışmasında, daha önceki uygulamalarda da gözetilen söylem çözümleme önermelerinin tamamı işe 
koşulmuş, sürecin sonunda ölçütlerde ifade hedeflerin tamamına ulaşıldığı görülmüştür. Ayrıca bu kaydedilen ilerleme ve aşamalar çizgi Grafik 6’da bütüncül bir şekilde gösterilmiştir.

Grafik 6: Deney Grubu Değerlendirme Formu Soru Ortalamaları

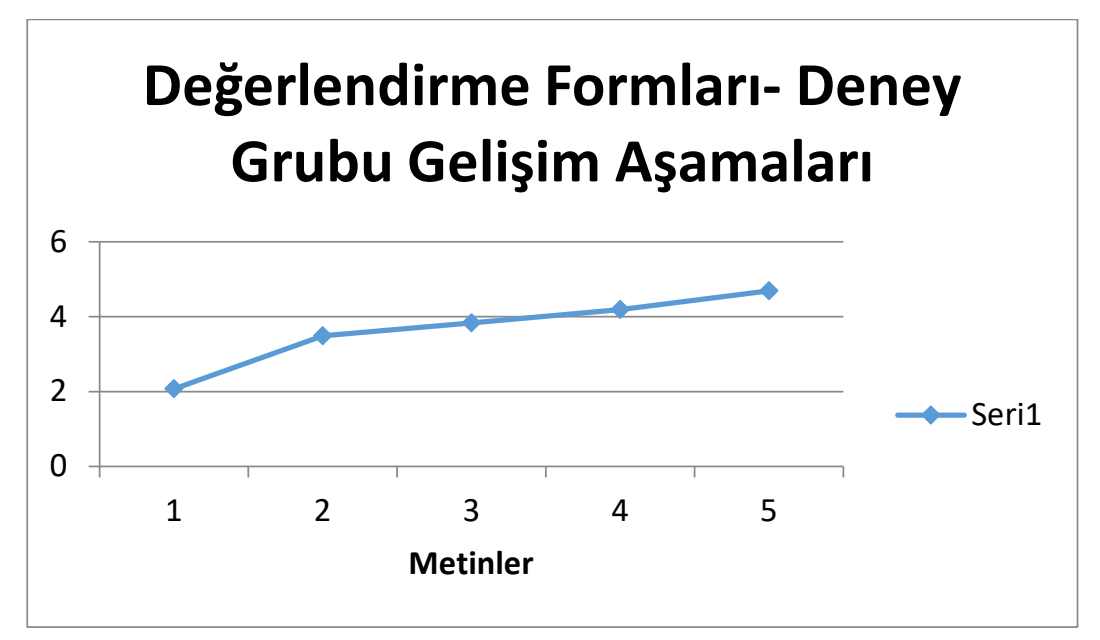

Ben Bir Küçük Kilimim (ön uygulama), Türküler Dolusu, Mutluluk Nedir, Kız Kalesi ve Türküler Dolusu (son uygulama) ortalamaları Tablo 12'de toplu olarak ve sıralı bir şekilde verilmiştir. Sürecin başından sonuna değin öğrencilerin yazma becerisinde kaydettikleri başarı, değerlendirme formlarına da yansımış, bu da yukarıdaki grafiklerde gösterilmiştir.

\section{Nitel Verilerin Analizi: Görüş Formları Bulguları}

Söylem çözümleme yönteminin öğrencilerin yazma becerisine dair kazanımlardaki etkisini araştırmaya yönelik olarak yapılan bu çalışmada deney grubu öğrencilerinin görüşlerini almak üzere 14 sorudan oluşan bir görüş formu uygulanmıştır. Forma uygulanan içerik analizi sonucu 2 Tema ve 3 kategori tespit edilmiştir:

\section{Tablo 5}

Görüşme Formlarının İçerik Analizi 


\begin{tabular}{|c|c|c|}
\hline \multicolumn{2}{|c|}{ 1. Tema: Referans Çerçeve ve Öğrenme } & \multirow{2}{*}{$\begin{array}{l}\text { 2. Tema: Duygusal Farkındalıklar } \\
\text { Duyuşsal Tasarımlar Kategorisi }\end{array}$} \\
\hline $\begin{array}{l}\text { Yöntemsel Göstergeler } \\
\text { ve İşlevsellik Kategorisi }\end{array}$ & İşlemsel Bilgi ve Davranışına Dönüklük K. & \\
\hline Farklı bakış açısı kazandırma & Yeni düşünceler üretme & Başarı duygusu oluşturma \\
\hline $\begin{array}{l}\text { Düşüncelerin ortaya çıkmasına katk1 } \\
\text { sağlama }\end{array}$ & Arka plan bilgisini fark etme & Yapabilme yönünde inanç / özgüven verme \\
\hline Hayal gücünü artırma & Yazarın tercihlerin anlama & Yazma becerisini fark etme \\
\hline Öğretici olma & Farklı cümleleri anlama & Keşfetme duygusu \\
\hline Etkin katılım sağlama & Sözcüklerin anlamsal değerini fark etme & $\begin{array}{l}\text { Güdülenme (yöntemin eğlenceli gelmesi } \\
\text { nedeniyle) }\end{array}$ \\
\hline Uygulama yapabilme olanağı sağlama & $\begin{array}{l}\text { Metinlerin yazılış amacına göre farklılıklarını } \\
\text { öğrenme }\end{array}$ & \\
\hline Kendi düşüncesini ortaya koyabilme & Dil bilgisi yapılarının anlama katkısını öğrenme & \\
\hline Eleştirel yaklaşabilme & Sözcüklere anlam yükleme & \\
\hline Yazma becerisini fark etme & $\begin{array}{l}\text { Çok anlamlılığ } 1 \text { fark etme ve yazıda } \\
\text { uygulayabilme }\end{array}$ & \\
\hline Düşünceleri açıklamaya firsat verme & Daha iyi cevaplar verebilme & \\
\hline Soru sorma becerisi kazandırma & Metin üretme & \\
\hline \multicolumn{3}{|l|}{ Üsluba katkı sağlama } \\
\hline Daha çok düşündürme & & \\
\hline
\end{tabular}

\section{Yöntemsel Göstergeler ve İşlevsellik Kategorisine Dair Bulgular}

Söylem çözümleme yöntemiyle ders işlenen ve yazma çalışması yapılan deney grubu öğrencilerine sürecin sonunda uygulanan görüş formunda Yöntemsel Göstergeler ve İşlevsellik olarak ifade edilen kategori; farklı bakış açısı kazandırma, düşüncelerin ortaya çıkmasına katkı sağlama, hayal gücünü artırma, öğretici olma, etkin katılımı sağlama, uygulama yapabilme olanağı sağlama, kendi düşüncesini ortaya koyma, eleştirel yaklaşabilme, yazma becerisini fark etme, düşünceleri açıklamaya firsat verme, soru sorma becerisi kazandırma, üsluba katkı sağlama, daha çok düşünme yönünde bir farkındalık ve beceri kazandırma kodlarından oluşmuştur.

Bu kategori bağlamında sorulan sorulardan elde edilen cevaplara göre söylem çözümleme yönteminin herhangi bir yazma çalışmasında yeni fikirler geliştirme, var olan fikirleri zenginleştirme, farkl1, özgün ve diğer üretilen bilgilerden ayırt edilebilecek düzeyde ürünler koyabilmesi bağlamında katkısının olduğu anlaşılmıştır. Söylem çözümleme sürecinde öğrencilerin aktif katılımı gerekir, zira yaratıcılık yeni ürünler ortaya koymayı ve yeni çözümler üretmeyi, bir senteze ulaşmayı öngörür. Bu anlamda öğrencilerin görüş formuna yansıyan cevapları şu şekildedir:

“Evet, oldu, çünkü bu yöntemle daha yeni fikirler ortaya koyabildim.” (Ö-6)

“Evet oldu, metne yeni bakış açılarıyla bakmayı öğrendim.” (Ö-3) 
“Evet, oldu, çünkü okuduğumuz metinler hayal dünyamın güçlenmesini sağladı.” (Ö-8)

“Oldu. Çünkü bizim düşüncelerimizden farklı anlamların da olduğunu gördüm.” (Ö-10)

Görüş formunda beyan edilen öğrenci görüşlerini desteklemek amacıyla örnek öğrenci ürününe yer verilmiştir:

(...) bu bir ortak bilinçtir, ortak düşüncedir. Yazar, Kız Kalesi'nin hikâyesini gençlere yani yeni kuşaklara ulaşmasını istemiştir. Geçmişte yaşanan bir hikâyenin yazıya geçirilerek topluma kazandırılmasını, aktarılmasını hedeflemiştir. (Kız Kalesi metni yazma çalışması-Ö: 9)

Kız Kalesi adlı metin üzerinden yapılan yazma çalışmasında; öğrencilerden, yazarın/anlatıcının metinle ulaşmak istediği toplumsal hedeflerinin olup olmadığı konusunda metne dair bilgilendirici bir yazı yazmaları istenmiştir. Bu yazma çalışmasıyla hedeflenen, metinde gösterilen unsurlar yoluyla yazarın/anlatıcının niyetinin ne olduğunun öğrenci tarafından anlaşılmasıdır. Bu anlamda var olan bilgi ile kendi düşüncelerinin sentezlenmesi amaçlanmış, metinle ilgili genel bilinen olguların dışında yeni, özgün metinler oluşturmaları istenmiştir. Nitekim söylem çözümleme yöntemi ile yapılacak yazma çalışmalarında yazarın metinle ulaşmak istediği toplumsal amaçlarının anlaşılması önemlidir; zira dil pratikleri, kişilerin yaşam algılamalarını ve zihinsel süreçlerini biçimlendirir.

Yaratıcı düşünme her şeyden önce hayal gücüne dayalı fikirler üretme olarak özetlenir. Öyle ki bu düşünme becerisinin en temel ifadelerinden biri; herhangi bir sorunun ortadan kaldırılmasında yani çözümünde sıra dışı, herkesin aklına gelmeyen, daha önce başkaları tarafından düşünülmemiş bir düşünceyi, davranışı ortaya koymaktır. Süreç boyunca öğrencilerin yazdıkları da söylem çözümleme yönteminin yaratıcı düşünme becerisini ortaya koyan ve geliştiren bir yöntem olduğunu göstermiştir. Bu noktada, Türküler Dolusu adlı metin yazma çalışmaları bağlamında ele alınmış yaratıcı düşünme becerisinin yazılan metinlerde gözlenebilmesi adına, öğrencilerden, metnin okuru olarak şiirdeki rolümüzün (okuyucunun rolünün) ne olduğu konusunda tartışmacı anlatım yöntemini merkeze alan bir yazı kaleme almaları istenmiştir. Bu metnin söylem çözümleme yönteminin yaratıcılıkla ilgili olan dizimsel bağlantıların dışında söylemin derin yapıları içinde ne gibi anlamlarının olduğununun özgün 
ve yaratıcı olarak belirlenerek ortaya konması olarak yazma çalışması gerçekleştirilmiştir. Bu anlamda yazılan metinlerde öğrenciler şu ifadeleri kullanabilmişlerdir:

Şair, metinde kendini anlattı̆̆ gibi bizi de şiire çağırıyor ve okuyan kişide bir anlam, düşünce kurgusu bırakıyor. Böylelikle şair bizi de şiirin bir parçası olarak kabul ediyor. (Türküler Dolusu metni yazma çalışması-Ö: 3)

Yazma stratejilerinin uygulanması Türkçe Öğretim Programı'nında önemli kazanımlarından biridir. Yazma tür, yöntem ve teknikleri içerisinde yer alan birçok unsur öğrencilerin yine üst düzey düşünme becerilerini ortaya çıkarabilmek adına düzenlenmiştir. Zira yazma becerisi ve eğitimi; düşüncenin ifadesidir. Düşüncenin dışa vurulması yollarından biri olan yazma eylemi, ayrıca bir üretim sürecidir. $\mathrm{Bu}$ anlamda yazma becerisi ifade edildiği üzere düşünme becerilerinden bağımsız düşünülemez. Bu bağlamda öğrencilerden yazma tür, yöntem ve tekniklerinden birini kullanarak söylem çözümleme yöntemiyle bir metin oluşturmalarına olan etkisini bağlamında yapılandırılmış sorulara öğrencilerin verdikleri cevaplardan bazıları şu yöndedir:

“Evet, yapabilirim, çünkü işlediğimiz metinlerden öğrendiklerimiz bize daha çok eleştirel bakmayı düşündürtüyor.” (Ö-1)

"Evet düşünüyorum. Metne bakış açısının daha eleştirel olması ve (metinde) daha farklı kelimelerin, cümlelerin de olabileceğini düşünüyorum.” (Ö-11)

Yukarıdaki öğrenci ifadelerinden de görüleceği üzere söylem çözümleme yöntemi eleştirel düşünmenin merkeze alındığı bir boyutla metinler oluşturmayı ifade eder. Eleştirel düşünme sorgulayan bir yaklaşımdır. İrdeleyici bir bakış açısı, yorum yapabilme becerisi gibi unsurları içerir. Zira eleştirel düşünen bireyler gerçeğin kendilerine aktarıldığı şeklinden daha farklı da olabileceğini düşünür ve daha nesnel bir bakışla akıl yürüterek gerçeğin ardından giderler. Söylem çözümleme metnin semantik ve söz dizimsel görünüşünün ötesine geçmek suretiyle metni meydana getiren kişinin niyetinin anlaşılmaya çalışılmasıdır. Başka bir ifadeyle makro yapının ötesinde metni oluşturan kişinin yani yazarın seçimleri, hangi durumda neyi neden kullandığı, neden bu şekilde söylediği gibi söylem düzeyi ve katmanlarını da analitik hale getirmeyi amaçlar. Bu da haliyle yazma eylemini gerçekleştirirken eleştirel bir bilişsel 
süreci hâkim kılmayı gerektirir. Aynı zamanda öğrenci yazma stratejisini kendisi belirleyeceğinden metabilişsel bir düşünme sürecini de işe koşmayı gerekli kılmaktadır. Söylem çözümleme yöntemi ile yapılan yazma çalışmalarında söylem çözümlemenin analizi yapana yüklediği birtakım sorumluluklar bu bakımdan metabilişsel düşünme becerilerini de öğrencilere kazandırmış ve kendi yazma yöntemlerini keşfetme olanağı sağlamıştır. Metnin türünün anlaşılması, metnin neden bu şekilde yazılıp başka şekilde yazılmadığının anlaşılması, yine metin türünün değişmiş olduğu farz edilirse başka ve farklı düşüncelerin ortaya konabilirliği bağlamında öğrenci yazılarına yansıyanlardan örnekler şu şekildedir:

Yazar bu metni yazarken bizde o anı canlandırıyor. Bu da aklımızda kalıcı olmasını neden oldu. Eğer başka şekilde yazsaydı bizdeki kalıcılığı, etkisi daha az olacaktı. (Ben Bir Küçük Kilimim- Ö: 1)

Bu şekilde değil de başka şekilde oluşturulsaydı farklı bir düşünce olmazdı. Çünkü konu aynı kalır sadece dilin işlevi yönünden değişirdi. (Ben Bir Küçük Kilimim- Ö: 11

Yazma eylemi de bir anlam aktarımı, bir anlatım yolu olması nedeniyle dilsel seçimlerin ve dilsel olguların sistematik bir şekilde işlenmesini gerekli kılar. Bu anlamda söylem çözümleme yöntemi hem yazma yöntem ve teknikleri içerisinde bu akıl yürütme işini ifade eden hem de üst düzey düşünmeleri gerekli kılan bir yöntemle anılmıştır.

Yine yöntemin etkililiğinin araştırıldığı diğer bir soruda söylem çözümleme yöntemiyle metinleri çözümleme noktasında kendilerini yetkin bulup bulmadıkları sorulmuş; şu yönde cevaplar alınmıştır:

“Evet düşünüyorum. Söylem çözümleme yöntemiyle cümlelerde daha farklı anlamlar olduğunu gördüm.” (Ö-10)

"Düşünüyorum. Kelimeler bildiğimiz anlamların dışında (kullanılmış) ben de bu türden yazmaya çalıştım.” (Ö-15) 
Yine bu anlamda yazma sürecinde öğrencilerin ‘fiil şekilleriyle temsil edilen eylemleri sırasıyla gerçekleştirmek için kişinin niyetli, bunları yapmak için istekli ve kararlı olduğunu, bu durumu zihinde tasarladı̆̆ını ortaya koymak’ yönergesi bağlamında metinleri kaleme aldıkları gözlemlenmiştir. Zira söylem çözümleme yönteminde kiplik belirleyicilerin önemli bir yeri vardır. Metin oluşturulurken ne tür eylemlerin kullanıldığı, metnin eylem pratiklerinin metnin esas konusu olan kişiler veya nesnelerle beraber kullanımının ne tür süreçlere karşılık geldiği gibi unsurlar söylem çözümleme yöntemi ile yapılan yazma çalışmalarında önemli bir paya sahiptir. Öğrenci ürünlerinden örnekler vermek gerekirse;

Büyük emeklerle dokumuştu kilimi annesi. Sıra boyamaya gelmişti. Şimdi bunu fabrika boyasıyla boyarlar mı diye düşündü ve üzüldü. Hemen annesinin yanına gitti: 'İzin ver biraz kök boya bulayım, kilime süreyim, hemen gelirim.' dedi. Annesinin cevabını beklemeden yeşil çayırlara koştu. (Ben Bir Küçük Kilimim-Ö: 10)

Yukarıda belirtildiği gibi eylemleri sırasıyla gerçekleştirmek için niyeti, isteği ortaya koymayı ve bunu bilişsel bir tasarlamayla yaptığı öğrencinin bu yazısından anlaşılmaktadır.

Yine 'düşünme, anlama ve sezgi yeteneğine dayanarak bir olayın gerçekleşip gerçekleşmeyeceğini tahmin etmek' yönergesi bağlamında ise öğrenciler örnekteki şekilde ifadeler kullanabilmişlerdir:

Zaman gelir, kilimler dokunur, kilimlerle ilgili söylenenlerden usanılır. (Ben Bir Küçük KilimimÖ: 5)

Öğrencilerin gerek yazdıkları metinler gerekse görüşme formundaki ifadelerinde de görüleceği üzere yöntem, öğrencilere söz varlı̆̆ içinde her gün kullandığımız sözcüklerin iletişimsel veya anlamsal değerinin dışında da kullanılabildiğini göstermiş ve bazı öğrencilerde yazma çalışması esnasında bu yönde bir davranış değişikliği de yaratmıştır. Bu anlamda da bir öğrenme durumu gerçekleştiği söylenmelidir. Söylem çözümlemesinin temel iddialarından içeriğin nasıl, hangi yol ve seçimlerle, hangi bağlamda, hangi niyetle, kim tarafından, kime aktarıldığının araştırılması ve ortaya çıkarılması, bu bağlamda yöntemin etkililiği adına bu soruya yanıt olarak verilen görüşlerde ve öğrenci yazılarında 
kendini göstermiştir. Öğrenciler genelde metinlerin niyet ve yapı açısından farklılıklarına dair farkındalıklarının arttığı yönünde görüş belirtmişlerdir. Zira söylem bir anlamlandırmayı ifade eder. Metinler de bu anlamlandırma boyutunun somut olgularıdır. Yapısal özellikleri ve dil kurgusunu doğru anlamak aynı zamanda metin-söylem ilişkisini de ortaya koymaktır. Dolayısıyla, söylem çözümleme yönteminin, öğrencilerin, metin çözümleme sürecinde ortaya koyduklarıyla herhangi bir bildirişimi analitik hale getirme sürecinde etkili bir yöntem olduğu söylenebilir.

Söylem çözümleme yönteminin yazma çalışmalarında amaca uygun seçimler yapma konusunda imkân verip vermediği yönündeki öğrenci görüşleri de araştırılmıştır. Zira söylem çözümleme yöntemi süreçte yazma pratikleri ve kurallarının söylem çözümleme merkezli olarak yapılandırılmasını ön görmektedir. Dilsel bileşenler sözün anlamlı olmasını sağlayan yapılardır ve yazma eylemine yazınsal bir özellik katarak onu da anlamlı hale getirir. Gerek dil bilgisel yapıları ortaya koymada gerekse cümlenin dizimsel boyutu açısından, bu seçimler cümlelerin anlamlandırılmasını sağlar. Öğrencilerin bu seçimleri hangi bağlamda ve yöntemin hangi özellikleri yoluyla yaptıkları cevaplara şu şekilde yansımıştır:

"Evet yapabildim. Çünkü bir sözcük bir makalede başka bir anlama geliyorsa hikâyede başka anlamlara da gelebilir.” (Ö-1)

“Söylem çözümleme, bize amaca uygun seçimler yapmayı öğretti. Metnin türüne göre sözcükler kullandık.” (Ö-10)

“Evet, imkân verdi. Mesela makalede yer alan bir sözcük bir şiirde farklı olarak kullanılmıştır.” (Ö-13)

Yine yazma çalışmaları sonucu ortaya konan ürünlerde de öğrenciler bu durumu somutlaştırabilmiş ve oluşturdukları metinlere yansıtabilmişlerdir. Yazarın metnin konusuna yönelik takındığı tutumu gösteren yapılardan bazıları zarf, sıfat gibi sözcük türleridir. Söylem çözümleme yönteminde yazarın özellikle bunları seçmiş olmasının hatta onlarca seçenek varken neden belirli birini kullanmayı tercih ettiğinin bilinmesi önemlidir. Bu durum yazarın okuyucusuyla olan ilişkisini ortaya koymasının yanında yazarın metnin konusuna olan kişisel tavrını da ifade etmektedir. Bu bağlamda 
öğrencilerden bir yazar olarak metnin konusuna yönelik olarak takındıkları tavrı gösteren bir metin yazmaları istenmiş ve yukarıda bahsi geçen bu seçimleri şu şekilde ortaya koymayı başarmışlardır:

Köyüme yani güzel Anadolu’ma eşsiz sevgimi dile getiriyorum. İçerisine insan kokusu sinmiş mısralar gibi vurgunum Anadolu’ya. (Türküler Dolusu metni yazma çalışması- Ö: 13)

Öğrenciler metinlerin türlerine göre dilin ve dille ilgili seçimlerin haliyle söylemin farklılaşacağını anlamış, yazma sürecinde yapılan çalışmalarda da bunu metinlere yansıtabilmişlerdir.

Günümüzde öğrenme stratejisinin bir şekilde edinilmesi ve öğretilmesi zorunlu hale gelmiştir. Öğrenmenin temelini oluşturan genel bir bakış açısının gerekliliği öğrenme hedeflerine ulaşmada önemli bir faktördür. Amaçlara ulaşmak için bilinçli olarak seçilen ve izlenen metot olarak adlandırılan yöntemin, öğretimin her aşamasındaki önemi herkes tarafindan kabul edilmektedir. Bu anlamda söylem çözümleme yöntemiyle yapılan yazma çalışmasında öğrencilerin süreç içerisinde bu yöntemin özelliklerini öğrenme ve uygulayabilme göstergeleri, hedeflenen amaçlara ulaşılmasında önemli sonuçlar olarak görülmektedir. Görüşme formundan elde edilen bulgular ve kodlara yansıyan ifadeler, süreçte yapılan yazma çalışmaları yöntemin anlaşıldığını ve uygulandığını göstermektedir.

\section{İşlemsel Bilgi ve Davranışına Dönüklük Kategorisine Dair Bulgular}

Öğrenmede önemli olanın yaşantılar yoluyla elde edilmesi ilkesi ile birlikte bunun kalıcı bir şekilde davranışta da gözlemlenebilir olmasıdır. Yazma çalışması esnasında yapılan gözlemler ve öğrencilerin ürettiği metinler bağlamında, söylem çözümleme yöntemiyle gerçekleştirilen öğrenme durumları gözlemlenmiştir. Görüşme formunda yöntemin etkililiği ve öğrenme süreçleriyle ilgili ‘İşlemsel Bilgi ve Davranışa Dönüklük’ kategorisinde yeni düşünceler üretme, arka plan bilgisini fark etme, yazarın tercihlerin anlama, farklı cümleleri anlama, sözcüklerin anlamsal değerini fark etme, metinlerin yazılış amacına göre farklılıklarını öğrenme, dil bilgisi yapılarının anlama katkısını öğrenme, sözcüklere anlam yükleme, çok anlamlılıkları fark edebilme ve yazıda uygulayabilme, daha iyi cevaplar verebilme ve metin üretme kodları belirlenmiştir. 
Şüphesiz bütün öğrenme süreçlerinin nihai hedefi olan üst düzey öğrenmelerin öğrencilerin, kendi düşünme süreçlerinin farkında olması ve kontrol etmesi olarak tanımlanan metabilişsel düşünmedir; bu bağlamda öğrencilerin verdikleri cevaplar şu şekildedir:

“Metinde verilen tüm parçaları bir araya getirerek farklı şeyler yaptık.”(Ö-1)

“Öğretmenin verdiği parçalar ve soruları daha iyi açıklayabileceğimi düşünüyorum.” (Ö-11)

“Öğretmenin verdiği parçaları bir araya getirdik. Daha anlamlı yapılar olacağını keşfettik.” (Ö-17)

Yazma çalışmaları sürecinde, organizasyon, analiz, sentez becerileri, söylem çözümleme yönteminin temel argümanını oluşturmuştur. Bir bütündeki her parçanın ayrıştırılıp bütünle ilişkisinin ortaya konduğu düşünme becerisi olan analitik düşünme, bahsi geçen organizasyon, analiz ve sentez becerileriyle bir arada konumlandırılan üst düzey becerilerdendir. Bu doğrultuda öğrencilerden $K l z$ Kalesi metninin toplumsal sonuçlarını değerlendiren bir yazı yazmaları istenmiştir. Zira metnin toplumsal sonuçlarının belirlenmesi söylem çözümleme yöntemi içerisinde bağlam unsuruyla ilgilidir. Metin ile toplumsal ve kültürel süreçler arasındaki ilişkiyi açıklamış olmanın yanında sonuçlarının bilinmesi de önemlidir; çünkü söylem pratiklerinin metin ve toplum arasında bir köprü işlevi gördüğü bilinmektedir. Metnin üretimi ve daha sonra dağıtılması söylemin sosyal eylem boyutunu ortaya koymaktadır. Bu anlamda öğrencilerin kaleme aldıkları metinlerde bu durum gözlenmiş ve yazılarına şu şekilde yansımıştır.

Toplumu ilgilendiren bir duygu ve düşünce olabilir. Bir kültür de olabilir. Toplum içerisinde yaygınlaştırmak, Kız Kalesi’nin nasıl yapıldı̆̆ını, o kültürün bilinmesini gerektirmektedir. (Kız Kalesi yazma çalışması- Ö: 17

Bir toplumda duygunun kökleşmesini ve aktarılmasını istemiş. Bunun herkes tarafindan bilinmesini istemek, unutulmamasını sağlamak ve en önemlisi bu kültürün kavranmasının sağlanmak istenmesidir. (Klz Kalesi yazma çalışması-Ö: 11

$\mathrm{Bu}$ bağlamda yapılan araştırma sonucunda, gerek yazma çalışmalarında gerekse görüş formlardaki öğrenci beyanlarında bu türden bir öğrenmenin gerçekleştiği sonucuna ulaşılmıştır. Bu 
anlamda söylem çözümleme, ortaya koyduğu yöntemsel bilgi, beceri, donanım ve öğrenme ortamlarıyla öğrencilere bu türden becerilerin kısa sürede kazandırılmasında etkilidir.

Söylem çözümlemenin önemli yapılarından biri de dil bilgisi kural ve yapılarının anlamla olan ilişkisidir. Bu aynı zamanda söylem çözümleme yönteminin yazma becerisi üzerinde etkisinin temel yapılarından birini teşkil etmektedir. Öğrencilere söylem çözümleme yönteminden sonra dil bilgisi kurallarının ve kullanım şekillerinin anlama katkı yaptığı bilinciyle yazılarını oluşturup oluşturmadıkları sorulmuş ve örnekler vermeleri istenmiştir. Bu soru yoluyla öğrencilerde, yazma sürecinin de en önemli unsurlarından olan, özellikle anadil kullanma yönünde bir farkındalığın gelişip gelişmediğinin anlaşılması amaçlanmıştır. Söylem çözümleme, metinlerin (dilin) semantik ve sentaktik yapısını inceler, oluşum süreçlerini ele alır ve söylemlerin hem dilbilimsel hem de sosyo-kültürel boyutları ile ilgilenir. Ayrıca herhangi bir yazının metin olmasında ve metne anlam katma konusunda bağdaşıklık ilkeleri söylemin biçimini, içeriğin nasıl düzenlendiğini ortaya koyan bir bağlam özelliğidir. $\mathrm{Bu}$ anlamda öğrencilerin bu süreçle ilgili öğrenmeleri formlardaki cevaplarına şu şekilde yansımıştır:

“Fiil kiplerinin cümlenin anlamına etki ettiğin öğrendim. Yazarın niyetini de buradan anladık.” (Ö-1)

“Mesela eksiltili bir yapıda yazarın niyetinin ne olduğunu öğrenebiliriz” (Ö-2)

“Bazı yapılarda yazarın arka tarafta hayal dünyasını anladık” (Ö-17)

“Mesela kullandığımız sıfatlar, zamirler, zarflar. Bunların cümleyle anlam kattığını düşünüyorum.” (Ö8)

Öğrencilerin yazdıkları metinlerde bu durum gözlenmiş; bir yazar olarak metnin konusuna yönelik oluşturdukları tutumu başta kip formları olmak üzere sözcük türlerini kullanma şeklinde göstermişlerdir. Yine sentagmaların, modalite leksemlerinin (kiplik leksemleri) ve diğer dilbilgisi kategorilerinin anlamla olan ilişkisini, metinde geçen bu yapıların anlamı nasıl etkilediğini ve yazarın bu seçimleri neden yaptığını bu anlamda ifade edebilmişlerdir. Ayrıca bu durumun değerlendirilmesinin istendiği bir eleştiri yazısında şu değerlendirme ifadelerini kullanabilmişlerdir. 
Şair bu mısrada kendini anlatmak istemiş ve köyüne, Anadolu'ya duyduğu sevgiyi dile getirmiştir. Örneğin bunu, içine insan kokusu sinmiş mısralara vurgunum gibi sıfatlar kullanarak anlatmış. (Türküler Dolusu yazma çalışması- Ö: 1)

Yazar metni okuyacak kişinin kendisiyle aynı şeyleri düşünmesini istediği için bu sözcükleri seçiyor. Çünkü mutluluk herkesi ilgilendiren bir duygudur. Bu seçimleri de okuru kendisi gibi düşündürmek içindir. (Mutluluk Nedir yazma çalışması- Ö: 2)

Yazarın sözcük seçimleri okuru metnin içinde olmasını istediği içindir. Yazar ve okuyucu arasında bir anlatım için bu sözcük türlerini, ünlemleri ve diğer sözcükleri kullanıyor. (Mutluluk Nedir yazma çalışması- Ö: 17)

$\mathrm{Bu}$ anlamda, bu çalışma yoluyla, söylem çözümleme yönteminin en grift ama en temel boyutlarından olan dilin kullanım olanakları ve anlatımsal gücünü belirten yapıların keşfedilmesi gerçekleşmiştir. Söylem çözümleme yöntemiyle bu durum öğrenciler tarafından anlaşılmış, hem yazma uygulamalarına hem de görüş formlarına yansımıştır.

\section{Duyuşsal Tasarımlar Kategorisine Dair Bulgular}

Söylem çözümleme yöntemi, süreçte yazma çalışmasının sadece bilişsel boyutuyla ilgili bir inisiyatif almamış aynı zamanda taksonomik bir değer olarak duyuşsal alan önermelerini de önemsemiştir. Bu anlamda Duyuşsal Tasarımlar kategorisi; başarı duygusu oluşturma, yapabilme yönünde inanç / özgüven verme, yazma becerisini fark etme, keşfetme duygusu ile yöntemin eğlenceli gelmesi ve keyifli olmasından ötürü oluşan güdülenme duygusu kodlarından meydana gelmiştir. Bu bağlamda, yöntemin uygulandığı derslere yönelik sorulan sorulara ilişkin öğrenci görüşleri şu yönde olmuştur:

"Fikirlerimize önem verildi. Kendimizi ifade edebildik. Soruları cevaplayabileceğimi fark ettim.” (Ö2)

"En beğendiğim nokta, kendi fikirlerimizi elde ederek öğretmenimize aktarabilmekti. Bu bizi çok mutlu etti.” (Ö-11) 
"Bu yöntem bizim metinleri heyecanla çözmemizi sağlad1, sanki bir labiret oyunu gibi merak ettirici bir şekilde çıkışı bulmamız gerektiğini öğretti.” (Ö-1)

Bundan sonraki derslerde söylem çözümleme yönteminin kullanılıp kullanılmaması tercihine yönelik soruya ilişkin öğrenci görüşleri şu şekildedir:

"Evet, daha etkin katılıyorduk ve düşüncelerimi daha rahat açıklıyordum. Başka derslerde de kullanılmasını istiyorum." (Ö-8)

"Evet tercih ederim. Çünkü eğlenceliydi. Başarılı olmak güzeldi.” (Ö-12)

Özellikle başarı duygusunun süreç içinde öğrenciler tarafından tadılmış olması, kendinin ve fikirlerinin değerli olduğu hissini de beraberinde getirmiştir. Bu durumda öğrenciler, herhangi bir davranışı ortaya koymak adına daha istekli hale gelmiştir. Söylem çözümleme yöntemi öğrenme sürecinde güdüleyici de bir rol üstlenmiştir.

Söylem çözümleme yönteminin yazma becerisi bağlamındaki bilişsel yapılar üzerindeki etkisinin duyuşsal etki alanında gözlemlenen bir durumu da şu şekilde meydana gelmiştir: Öğrencilerin bir konu üzerinde düşünmeleri, duygu ve düşünceleri anlamaları sonucunda çözümler üretmeleri; grup içinde konuşma ve kendilerini ifade etmeleri yönünde daha rahat ve özgüven içinde hissetmelerine olanak sağlamıştır. Ayrıca yine süreçte ürettikleri fikirlerin kabul görmesi, fikir üretim işlemi açısından teşvik edici bir boyut halini de almıştır. Böylelikle bir şeyi başarma konusunda daha cesaretli bir tavır içine de girmişlerdir.

Söylem çözümleme yöntemi ve dil zevkinin gelişimi arasındaki ilişkiye yönelik de öğrenci görüşleri olumlu yönde olmuş, bazılarının ifadeleri aşağıda aktarılmıştır:

"Evet, geliştirdi. Kullanılan sözcüklerin bizim kullandığımız (anlamlardan) daha farklı olduğunu gördüm.” (Ö-10)

“Evet. Sözcükleri keşfettik.” (Ö-11) 
Görüleceği üzere, duyuşsal alan önermeleri özellikle bilişsel süreçlerle birlikte görülmüştür. Duyuşsal göstergelerle ilgili durumlar söylem çözümleme yöntemiyle yazma çalışmaları esnasında daha çok; ilgi duyma, farkındalık, etkileşim, başarı duygusunun beraberinde oluşan duygusal durumlar şeklinde kendini göstermiştir.

Sonuç olarak, söylem çözümleme yönteminin kodlarda belirtilen diğer unsurlarla birlikte duyuşsal alanda da etkili olduğu ve öğrencilerin başarılı olmasında bu yönüyle de önemli katkılarda bulunabileceği söylenebilir.

\section{Tartışma ve Sonuç}

Söylem çözümleme yönteminin 7. sınıf öğrencilerinin yazma becerilerine katkısının araştırıldığı bu çalışma süresince öğrencilerin yazdıkları metinler, görüşme formları ve gözlemler bağlamında şu sonuçlara ulaş1lmıştır:

Söylem çözümleme yöntemi, öğrencilere söz varlığı içinde her gün kullandığımız sözcüklerin iletişimsel ve anlamsal değerinin dışında da kullanılabildiğini göstermiş, bazı öğrencilerde yazma çalışması esnasında bu yönde bir davranış değişikliği de yaratmıştır.

Söylem çözümlemenin temel iddialarından içeriğin nasıl, hangi yol ve seçimlerle, hangi bağlamda, hangi niyetle, kim tarafından, kime aktarıldığının araştırılması ve ortaya çıkarılması, yöntemin, yazma çalışmalarındaki olumlu etkilerine temel oluşturmuştur. Yöntem, bu şekilde öğrencilerin metinlerin niyet ve yapı açısından farklılıklarına dair farkındalıklarını arttırmıştır. Söylem bir anlamlandırmayı ifade eder; metinler ise bu anlamlandırma boyutunun somut olgularıdır. Bu ilkeyi söylem çözümleme yoluyla anlayan öğrenciler ortaya koydukları ürünlerde de bunu dikkate almışlardır.

Ayrıca, söylem çözümleme yöntemi, metin çözümleme sürecinde ortaya koyduklarıyla herhangi bir bildirişimi analitik hale getirme sürecinde etkili bir yöntemdir, metni bu şekilde tam anlamıyla anlamlandıran ve çözümleyen öğrencilerin metinler üzerine yazdıkları yazılar da daha anlamlı olmuştur. Öğrenciler metinlerin türlerine göre dilin ve dille ilgili seçimlerin haliyle söylemin farklılaşacağını anlamış, yazma sürecinde yapılan çalışmalarda da bunu metinlere yansıtabilmişlerdir. 
Aynı zamanda yeni düşünceler üretme, arka plan bilgisini fark etme, yazarın tercihlerin anlama, farklı cümleleri anlama, sözcüklerin anlamsal değerini fark etme, metinlerin yazılış amacına göre farklılıklarını öğrenme, dil bilgisi yapılarının anlama katkısını öğrenme, sözcüklere anlam yükleme, çok anlamlılıkları fark edebilme ve yazıda uygulayabilme, daha iyi cevaplar verebilme ve metin üretme süreçlerinde de söylem çözümleme yönteminin katkısıyla daha başarılı olmuşlardır. Bunlara ek olarak; derslere etkin olarak katılarak söylem çözümleme yöntemi yoluyla metinleri anlamlandıran öğrenciler, başarı duygusunu da süreç içinde tadabilmiş, kendinin ve fikirlerinin de değerli olduğu hissetmiş, bu durumda öğrenciler herhangi bir davranışı ortaya koymak adına daha istekli hale gelmiştir. Böylelikle söylem çözümleme yöntemi öğrenme sürecinde güdüleyici de bir rol üstlenmiştir.

Toplumsal yapı ile dil yapıları arasında kuvvetli bir ilişki olduğu öğrenciler tarafindan anlaşılmış, özellikle sosyal eylemlerin birçoğunun dil kullanılarak gerçekleştiği ve bu durumun da anlatma yöntemlerinde görülebileceği yine öğrenciler tarafından fark edilmiştir.

Bilindiği gibi yazma ile düşünme arasında birbirinden ayrılamaz bir ilişki vardır. Yazma ile düşünce arasındaki ilişkide yazma, bir yönüyle düşüncelerimizin görülebilir olmasını, geliştirilmesini, sınırlandırılmasını ve değiştirilmesini; diğer yönüyle de bazı fikirlerin dışarıda tutulmasını sağlar (Fulwiler, 1982). Yazı, üretim sürecinin kendisi ve sonucudur. Bu üretim süreci, insan zihninde oluşan anlamın aktarılmaya karar verilmesi ve bu anlamın dilsel karşılıklarının tespiti ve seçimi ile başlayıp, bunların kullanılan dilin imkânları çerçevesinde kodlanması ile sonuçlanır (Özay ve Karadağ, 2013). Söylem çözümleme yöntemi hem anlamın ve fikirlerin oluşumunu, gelişimini, yeniden düzenlenmesini sağlaması yönüyle, hem de bunların sözlü ya da yazılı aktarımı sürecinde önemli bir yöntemdir. Söylem çözümleme yöntemiyle bir metin inşa etmek demek, sadece dilsel yapıların çözümlenmesi değil; aynı zamanda zihinsel boyutların da ortaya konmasıdır. Metnin iletişimsel boyutuyla ilgili bu durum öğrenciler tarafından yazılan metinlere yansımış ve söylem çözümleme yöntemiyle bu boyut, yazma becerilerine etki etmiş, metnin kodlarını doğru çıkaran öğrenciler, düşüncelerini ifade ederken yazma sürecinde de doğru kodları seçip kullanabilme becerileri gelişim göstermiştir. 
Söylem çözümleme hem anlama, anlamlandırma ve çözümleme, hem de çözümlemelerin doğru kodlarla etkili bir biçimde ifade edilmesi adına genel olarak Türkçe öğretiminde, özelde de yazma öğretiminde nitelikli ve amaca yönelik imkânlar sunan bir yöntem olarak görülmüştür. Bununla birlikte, hem öğrencilerin görüş formlarındaki beyanları hem de araştırmacının gözlemleri, söylem çözümleme yöntemi ile gerçekleştirilen Türkçe derslerinin metin çözümleme, analiz yapma ve bir senteze ulaşma, başka bir deyişle düşünceleri oluşturma ve yazıya dökme aşamalarında öğrencilerin ilgi, motivasyon ve derse katılımlarını olumlu yönde etkileyen bir yöntem olarak bulunmuştur. Öğretmenin, dersin içeriğine göre öğrencilerin zihinsel ve duyuşsal alanlarına hitap eden yöntemler kullanmasının; doğru ve etkili konuşmada, dinleme ve anlama gibi becerilerin kazandırılmasında uygun yöntem ile uygulamaların çokça gerçekleştirilmesinin, bu bağlamda da Türkçe derslerinde kullanılacak yöntemlerin öğrencilerin dil becerileri ile farklı bağlamlarda, farklı iletişim durumlarında kendilerini doğru ve etkili ifade etmelerini sağlamasının önemi (Calp, 2002; Göçer, 2010; Kavcar, Oğuzkan ve Sever, 1998; Ünalan, 2001) göz önünde bulundurulduğunda söylem çözümleme yönteminin çok yönlü katkılar sağlayacağ1 düşünülmektedir. Söylemle cümle arasındaki ilişki bu süreçte öğrencilere sezdirilmiş, dilbilgisel yapıların bağlamla ilişkisinin incelenmesi gerektiği yine öğrenciler tarafından anlaşılmış ve yazdıkları metinlerde bu ilişkiyi kullanabilecekleri becerileri elde edebilmişlerdir.

Doğru ve etkili yazma, yetenekten ziyade, yazma yöntem ve tekniklerinin iyi bir şekilde öğrenilmesine, metinlerin oluşumundaki temel dil kurallarının, sözcük, cümle ve paragraflara dair bilginin doğru kullanımına bağlıdır (Kantemir, 1991; Öztürk, 2007). Her metnin üretim koşulları, kullanılan dil, yapılar vs. birbirinden farklıdır. Metin ve söylem arasındaki bu ilişkiyi belirleyen bağlam ve düşünce yapısı farklılaştıkça metinlerin de türü ve dilsel yapısının değişeceği öğrenciler tarafından fark edilmiş ve bu olgu üzerine metinler üretebilmişlerdir.

Planlı yazma söylenenlerin doğru ve etkili anlaşılmasında, yazma sürecinde, sürecinden başından sonuna kadar çok önemli bir yere sahiptir (Adalı, 2003; Gökşen, 1980; Kantemir, 1991; Karatay, 2011; Özdemir, 1992; Par, 1997; Tekşan, 2001) Söylem çözümleme yöntemiyle öğrenciler, herhangi bir metnin rastgele dizilmiş cümlelerden oluşmadığını görmüş; her metnin kendi içinde belli 
bir bütünlük meydana getirdiğini anlamışlardır. Öğrendikleri bu yöntemle başta kelime seçimleri olmak üzere, metni meydana getiren bütün yapıları daha iyi organize edebilmiş ve yazdıkları metinlerde bu organizasyon becerisini de kullanabilmişlerdir.

Yine bu süreçte; metnin kim ya da niçin yazıldığı, dil ve anlatım unsurları açısından metinlerin neden farklılaştığını, farklı yazma şekillerine neden ihtiyaç duyulduğu gibi metinlerin üretim sürecine yönelik yapıları keşfetmiş ve yazma çalışmalarına bu üretim süreçlerini dâhil edebilmişlerdir. Yazma eğitiminde süreç odaklı yaklaşımın ürün odaklı yaklaşımlara göre daha etkili olduğu çeşitli çalışmalarda ortaya konmuştur (Cheung ve Chan, 1994; Cheung, 1999; Cheung ve diğ., 1992; Goldstein ve Carr, 1996; Jacob ve Talshir, 1998; Lee ve Yau, 1992; Lo, 1994; Mahon ve Yau, 1992; Stewart, 1986; Stewart ve Cheung, 1989; Tyson, 1999; Pennington ve Cheung, 1993; Pennington ve Cheung, 1995; Tabak ve Göçer, 2013; Zamel, 1982). Bu durum da göz önünde bulundurulduğunda, söylem çözümleme yönteminin hem okuma, anlama, çözümleme, yordama, eleştirme ve düşünce üretme süreçlerine hem de yazma sürecine odaklanması ve bu yöndeki kazanımları düşünüldüğünde, Türkçe öğretiminde etkili bir yöntem olarak belirmektedir.

Öğrenciler, metinlerini meydana getirirken söylem çözümlemenin imkânlarından yararlanarak düşüncelerin cümle ve paragraflarda nasıl yerleştirildiğini, sözcük ve cümle yapılarının anlama nasıl etki ettiğini, bu seçimlerin neden yapıldığını görebilmiş; metin üretirken bu unsurları göz önünde bulundurmuşlardır.

\section{Öneriler}

Buna göre, araştırmada ulaşılan sonuç ve tartışma bağlamında aşağıdaki öneriler getirilmiştir:

1. Sürece dayalı ve nitel kısmı da bulunan bu çalışma, yapısı gereği sınırlı sayıda 7. sınıf öğrencisi ile yapılmıştır. Diğer seviye grupları ile de çalışılarak sonuç değerlendirmesinin yapılması önerilir.

2. Metinlerin tür olarak farklılaştığını ve her metnin kendine özgü bir mimari yapısının ve dil hususiyetinin olduğunun kavratılması ve yazarken buna göre seçimlerin yapılması gerektiğinin öğretilmesinde söylem çözümleme yönteminden yararlanılabilir. 
3. Yazarken fikirlerin ya da olayların organize edilmesinde söylem çözümleme yöntemi; başta dil kullanımı, söylemin cümleye atfettiği anlamlar, dilbilimle olan ilişkisi, dilbilgisel yapılar ve bunların kullanımıyla ilgili perspektifi gibi geniş alanlar sunmaktadır. Özellikle süreç temelli yazma çalışmalarında amacın belirlenmesi, metnin okuyucusu olacak hedef kitleye göre bir metin üretilmesi, türün ne olacağına karar verilmesi, konuya uygun düşüncelerin oluşturulması ve ne şekilde verileceği, planlamanın yapılması gibi süreçlerde bu imkânlardan yararlanılabilir.

4. Herhangi bir yazıya metin dememizi gerekli kılan unsurların yani metnin anlamsal yapısıyla ilişkili olan bağdaşıklık yapılarının metin üretiminde daha etkili kullanılmasında söylem çözümlemeden yararlanılabilir.

5. Tüm süreçleri yürütecek olan kişi öğretmen olduğundan, öğretmenin söylem çözümleme yönteminin ilkeleri, işlevsel dilbilim ve edimbilim alanlarına hâkim olması, öğrencilerin de metinleri tam anlamıyla anlamalarına ve çözümlemelerine, dolayısıyla da yazma süreçlerine olumlu yönde etki edeceği düşünülmektedir.

\section{Makalenin Bilimdeki Konumu (Yeri)}

Türkçe Eğitimi ABD

\section{Makalenin Bilimdeki Özgünlüğü}

Türkçe dersi; anlama, dinleme, konuşma, yazma, metin analizi, sentez ve değerlendirme gibi önemli ve temel becerileri öğrenme hedef ve kazanımları olarak belirlemiş bir alandır. Bu nedenle, Türkçe derslerinde, öğrencilerimizin girdiği PISA gibi değerlendirmelerde ve artık eğitim sistemimizin de evrildiği açık uçlu, yordama, eleştirel düşünme, çıkarım yapma, bilgi, beceri ve birikimlerini kullanma ve başka alanlara aktarabilme becerilerini ve yetilerini kazandıracak, geliştirecek, günümüz ihtiyaçlarına cevap verebilecek yeni yöntemlerin geliştirilmesi ve kullanılması çok önemli bir husustur. $\mathrm{Bu}$ noktada öğrencilerin bu alanlardaki kazanımlarını arttıracak, onların hem anlama ve eleştirel 
düşünme becerilerini geliştirirken hem de eğlenerek gelişimlerini sağlayacak, derse katılımlarını arttırarak, özgüven, iletişim ve kendini doğru ifade edebilme gibi kişisel gelişim alanlarına da katkı yapacak olan söylem çözümleme yönteminin tanınması ve kullanılmasının önemi ortaya çıkmaktadır. Aslında bir araştırma yöntemi olan ve daha çok iletişim alanında kullanılan Söylem Çözümlemenin, başka alanlarda kullanıldığı çok az sayıda çalışma vardır, bu birkaç çalışma da genelde ikinci dil öğretiminde ve çeviri alanında yapılan çalışmalardır. Ancak, Söylem çözümlemenin bir öğretim yöntemi olarak çalışıldığı başka bir çalışmaya rastlanmamıştır. Bu nedenle, bu tarz çalışmalara öncül niteliğinde özgün bir çalışma ile katkıda bulunmak istenmiştir. Ayrıca, Türkçe derslerinde bir yöntem olarak kullanılması tarafımızca önerilen söylem çözümlemeye dair yapılacak çalışmalar, öğretmen ve aday öğretmenlerin bu yönde farkındalıklarının arttırılması adına söz konusu alanda ve alanyazında önemli bir konuma sahiptir.

\section{Kaynakça}

Acarlar, F. ve Dönmez, N. B. (1992). 30-47 aylar (2.5-4 yaş) arasındaki Türk çocuklarının dil yapılarının incelenmesi. Gazi Üniversitesi Gazi Eğitim Fakültesi Dergisi, 8(3), 63-203.

Acarlar, F., Ege, P. ve Turan, F. (2002). Türk çocuklarında üstdil becerilerinin gelişimi ve okuma ilişkisi. Türk Psikoloji Dergisi, 17(50), 63-73

Adalı, O. (2003). Anlamak ve anlatmak. İstanbul: Pan Yayınc1l1k

Aktaş, Ş ve Gündüz, O. (2003). Yazılı ve sözlü anlatım kompozisyon sanatı. Ankara: Akçağ

Akyol, H. (2006). Yeni programa uygun türkçe öğretim yöntemleri. Ankara: Kök Yayıncılık

Akyol, H. (2009). Türkçe ilk okuma yazma öğretimi. Ankara: PegemA

Balc1, A. (2011). Sosyal bilimlerde araştırma, yöntem, teknik ve ilkeler. Ankara: PegemA Akademi

Büyüköztürk, Ş. (2001). Deneysel desenler. Ankara: Pegem A Yay. 
Calp, M. (2002). Öğretmenler ve eğitim fakültesi sınıf öğretmenliği bölümü için ilk okuma yazma ögretimi. Erzurum: Bakanlar Matbaas1

Fairclough, N. (1995). Critical discourse analysis. Londra: Longman.

Fulwiler, T. (1982). Writing: An act of cognition. New Directions for Teaching and Learning, 1982 (12), 15-26.

Gill, R. (1996). Discourse analysis: Practical implementation. J.T. E.Richardson (Ed.). Handbook of Qualitative Research Methods for Psychology and Social Sciences. Leicester: British Psychological Society, $141-156$.

Gersten, R. ve Baker, S. (2001). Teaching expressive writing to students with learning disabilities: A meta-analysis. The Elementary School Journal, 101 (3), 251-272

Göçer, A. (2010). Türkçe öğretiminde yazma eğitimi. Uluslararası Sosyal Araştırmalar Dergisi The journal of International Social Research, 3 (12), 178-195

Gökşen, E. N. (1980). Kompozisyon ilkeleri ve antolojisi. İstanbul: Murat Ders Yayınları

Güneş, G. (2007). Türkçe ögrretimi ve zihinsel yapılandırma. Ankara: Nobel Yayın Dağıtım.

Güneş, F. (2013). Türkçe öğretimi yaklaşımlar modeller. Ankara: Pegem Akademi Yay.

Ege, P., Acarlar, F. ve Güleryüz F. (1998). Türkçe kazanımında yaş ve ortala sözce uzunluğunun ilişkisi. Türk Psikoloji Dergisi, 13 (41), 19-31

Hovardaoğlu, S. (2000). Davranış bilimleri için araştırma teknikleri. Ankara: VE-GA Yayınları

Kantemir, E. (1991). Yazllı ve sözlü anlatım. Ankara: AÜEBF Yayınları.

Karadağ, Ö. ve Maden, S. (2013). Yazma eğitimi: Kuram, uygulama ve ölçme değerlendirme. A. Güzel ve H. Karatay (Ed.), Türkçe öğretimi el kitabı (265-301). Ankara: PegemA Yayınları.

Karasar, N. (2013). Bilimsel araştırma yöntemi (25. Basım). Ankara: Nobel 
Karatay, H. (2011). 4+1 planlı yazma ve değerlendirme modelinin öğretmen adaylarının yazılı anlatım tutumlarını ve yazma becerilerini geliştirmeye etkisi. Turkish Studies. 6 (3), 1029-1047

Kavcar, C., Oğuzkan, F. ve Sever, S. (1998). Türkçe öğretimi, Türkçe ve sinıföğretmenleri için. Ankara: Engin Yayınları.

Miles, M. B. \& Huberman A. M. (1994). An expanded sourcebook: Qualitative data analysis. CA: Sage Publications.

Özdemir, E. (1992). Kompozisyon. İstanbul: Remzi Kitabevi

Öztürk, E. (2007). Yaratıcı yazmanın gelişim süreci ve ilköğretimde yaratıcı yazı yazma öğretimi. SAÜ Ĕ̈itim Fakültesi Dergisi, 14, 266-273

Par, A. H. (1997). Planlı yazma sanatı, kompozisyon. İstanbul: Serhat Yayınları

Potter, J. ve Wetherell, M. (1987). Discourse and social psychology. Londra:Sage

Sinclair, J.M. ve Coulthard, R.M. (1975). Towards an analysis of discourse: The English Used by teachers and pupils. Londra: Oxford

Tabak, G. ve Göçer A. (2013). 6-8. sınıflar Türkçe dersi öğretim programının ürün ve süreç odaklı yazma yaklaşımları çerçevesinde değerlendirilmesi. Ahi Evran Üniversitesi Kırşehir Eğitim Fakültesi Dergisi (KEFAD), 14 (2), 147-169

Tekşan, K. (2001). Yazılı anlatımı geliştirmede ön hazırlığın etkisi. Yayımlanmamış doktora tezi, Çanakkale 18 Mart Üniversitesi, Sosyal Bilimler Enstitüsü

Temizyürek, F. ve Çevik, A. (2017). 5. sınıf öğrencilerinin zihinsel tasarıma dayalı yazma modelini metin oluşturma sürecinde kullanma becerileri. Bartın Üniversitesi Eğitim Fakültesi Dergisi, 6 (1), 114-138.

Titscher, S., Meyer, M., Wodak, R. ve Vetter, E. (2000). Methods of text and discourse analysis. Londra: Sage 
Ünalan, Ş. (2001). Türkçe öğretimi. Ankara: Nobel Yayın Dağıtım

Ünveren, D. (2016). Muc’un ucuz evinde mucizenin ölümü: Didem Dadak’ın ‘Annemle İlgili Şeyler’ adlı şiiri üzerine söylem çözümlemesi. Turkish Studies International Periodical for the Languages, Literature and History of Turkish or Turkic, 11 (15), 609-632

Van Dijk, T.A. (1985). Discourse and communication: New approaches to the analysis of mass media discourse and communication. Berlin: Walter De Gruy

Yıldırım, A. ve Şimşek, H. (2011). Nitel araştırma yöntemleri. (8. Baskı). Ankara: Seçkin.

Yurdakul, B. (2015). Yapılandırmacılık. Ö. Demirel (Ed.), Eğitimde Yeni Yönelimler (39-61). Ankara: PegemA Yayınc1lik

Zamel, V. (1982). The process of discovering meaning. TESOL Quarterly, 16 (2), 195-209.

\section{Summary}

\section{Problem Statement}

Writing is not only an expression of feelings and thoughts but also a process that can result in people acquiring knowledge and consistent habits to mature cognitively. It is emphasized that the mental processes used in the writing process is important in cognitive development and have a function of regulating the structure of the mind. And for these reasons, it is thought to be even more important than reading. Discourse analysis is a comprehensive research method that deals with the output of meaning through verbal and written texts. Among the basic assumptions of discourse analysis are that; language is an instrument in action and function, people use it linguistically for certain purposes, and that this active process is reflected in the diversity of language. Language learning, even if it is native language learning, is more than knowing grammar rules, and requires learning the language in its use. Language is expressed in discourse; the discourse is shaped in context and the context occurs in the text. In written 
discourse, texts present different discourses and contexts by different types of texts. Using texts is very important at every level of the mother tongue or second language teaching process. What is important at this point is the understanding of the text. In this respect, the discourse analysis method helps getting into the essence and depth of the text. Thus, reaching the hidden essence lying beneath the surface presents a way to go beyond the boundaries of the sentence to ensure that the reader speaks the same language with the writer. The good method is needed not only in the writing process but also before starting to write, in the analysis of information and data, making sense of them and conveying it to the reader in the most appropriate way. Therefore, in this study, discourse analysis method was examined in terms of providing those opportunities, know-how, required skills and equipment and its effect on the writing process.

Purpose of the Study: In this study, it was aimed to examine the effect of discourse analysis method on writing skills, by taking $7^{\text {th }}$ graders as the sample of the study.

\section{Method}

In this mixed methods research, experimental study with pre-test post-test group in which the quantitative and qualitative data collection instruments were used to examine the effect of discourse analysis method on writing skills; the writing practices of the students were evaluated in various ways; quantitative data collected through 5-step-writing practices and an 7-criteria-evaluation form; and qualitative data collected through opinion forms; analysed by using content analysis method and also some examples were presented in descriptive way. According to the criteria in the evaluation form, the student scores were marked based on a likert scale. The answers structured by the students to the guiding questions in the 5-step writing practices which were conducted at the end of each process of analyzing texts by discourse analysis, were evaluated and results were analyzed. Participants consisted of 21 students in treatment and 19 students in the control group from $7^{\text {th }}$ graders. Before the groups were determined, information was obtained about the level of writing skills of the students, especially from 
the teachers of the relevant classes, specifically from social studies and Turkish courses. In addition, while creating groups, it was also ensured that two groups with similar achievement levels were selected by looking at the students' averages of Turkish lesson and the other courses of $6^{\text {th }}$ grade and $1^{\text {st }}$ semester of $7^{\text {th }}$ grade.

\section{Findings and Discussion}

It has been found out that the students were able to recognize elements and processes related to creating a text such as; how thoughts are placed in the sentences and paragraphs, how the words and sentences are located in texts to affect understanding and to create specific meaning and effect, why all these choices are made etc. by taking advantage of the opportunities of discourse analysis method. In addition, they also expressed positive opinions on discourse analysis method to be used in Turkish courses and that the method contributed to the development of skills such as comprehension and writing. Additionally, it has been understood by the students that there is a strong relationship between social structure and language structures and forms; especially they recognized that many of the social actions are carried out using language and this situation can be observed in various methods and types of writings.

There is a crucial relationship between writing and thinking. Writing is one of the ways through which our thoughts can be seen, improved, restricted and changed; and on the other hand it allows some ideas to be excluded. The writing is a production processes itself and also the output. This process of production begins with the decision to transfer the meaning and thoughts and the determination and selection of linguistic methods, ways or strategies to convey the meaning intended. This process results in the coding of those choices within the possibilities and opportunities of the language used. Discourse analysis is an important method in both the formation and rearrangement of ideas and meaning and in the process of oral or written communication to the target group. To construct a text by discourse analysis method is not only the analysis and synthesis of linguistic structures; at the same time, the cognitive dimensions of them are also revealed. This was reflected on the texts written by the students 
and this dimension influenced the writing skills of them and the students' ability to choose appropriate codes to express their thoughts in the writing process has also improved.

\section{Conclusion and Recommendations}

Discourse analysis can be used to teach that texts differ in kind/type and that each text has its own unique architectural/structural and linguistic features and that it is necessary to make choices accordingly. The method offers the wide range of perspectives and areas as; use of language, the meaning ascribed by discourse to sentences and their relationship with linguistics, grammatical structures and their usage. Particularly in process-based writing activities, it is possible to use these opportunities and possibilities in the processes such as determining the purpose, producing a text according to the target audience of the text, deciding what to do and forming the appropriate ideas. 